\title{
JUAN PACHECO. DE DONCEL DEL PRÍNCIPE DE ASTURIAS A MARQUÉS DE VILLENA (1440-1445)
}

\author{
JUAN PACHECO. \\ FROM THE PRINCE OF ASTURIAS' SQUIRE \\ TO MARQUIS OF VILLENA (1440-1445)
}

\section{AlFONSO FRANCO SILVA Universidad de Cádiz}

\begin{abstract}
Resumen: Es este trabajo se presenta, y se analiza con rigor, el proceso de ascenso de Juan Pacheco, nieto de nobles portugueses emigrados, desde su modesto puesto de doncel del Príncipe de Asturias - futuro Enrique IV - a señor de Utiel y de Moguer, para finalmente alcanzar, tras la batalla de Olmedo, nada menos que el marquesado de Villena, uno de los estados señoriales más poderosos del reino de Castilla.
\end{abstract}

Palabras clave: Juan Pacheco; Álvaro de Luna; Príncipe Enrique; Juan II; Utiel; Moguer; Marquesado de Villena.

\begin{abstract}
This paper introduces and analyzes the ascent of Juan Pacheco, granson of aristocratic portuguese emigres, from his modest position as squire to the Prince of Asturias (and future King Henry IV), to that of Lord of Utiel and Moguer, and eventually (after the battle of Olmedo) Marquis of Villena, one of the most powerful lordly estates in the Kingdom of Castile.
\end{abstract}

Keywords: Juan Pacheco; Álvaro de Luna; Prince Henry; John II; Utiel; Moguer; Marquisate of Villena.

\section{SUMARIO}

1. De doncel a señor de Utiel.- 2. La operación "Moguer".- 3. Del golpe de Rámaga a Olmedo. La incorporación del marquesado de Villena.- Apéndice documental.

El qual, según la spiriençía lo mostrava, el dicho Juan Pacheco le desviaba -al principe de
Asturias- de la opinión e obediencia del señor Rey su padre, e él mesmo lo tornaba a
rreconciliar. E esto fazia quando quería sacar del Rey algunas gruesas dádibas e merçedes; e por
esta vía e con esta plática sacó e alcançó tanto, que en spacio de seys años, dando cada año vna
vuelta, llegó a ser marqués e señor del marquesado de Villena, e señor de otros muchos
heredamientos e merçedes, asy de juro como de por vida. E asy mesmo por esta vía ovo, contra
toda justiçía, el maestradgo de Calatrava para su hermano Pedro Girón" (Crónica del Halconero
de Juan II. Edición de Juan de Mata Carriazo, Madrid, 1946, cap. CCLXIX, pp. 342-343).

E como Juan Pacheco su privado estaba cada día más apoderado de su voluntad, siempre consejaba al Príncipe que pusiese al Rey en necesidades, e que con esto el Príncipe y el serían más acrecentados en estado" (Crónica de Juan II, Madrid, BAE, 1953, Tomo LXVIII, año 1441, cap. V, p. 574).

Era el principal de ellos (los consejeros del príncipe de Asturias) Don Juan Pacheco, de extremada condescendencia y que todo lo sacrificaba a la ambición de mando, aún a costa de las mayores torpezas. Sagaz, diestro y astuto, habiale escogido Don Álvaro desde niño para doncel de Don Enrique, creyendo que no se desviaría un punto de sus instrucciones; por lo qual aconstumbraba elogiar su natural ingenio como ejecutor de la propia iniciativa, y se complacía en ensalzar sus cualidades y su disposición para todo género de servicios" (Alonso de Palencia, 
Crónica de Enrique IV, Tomo CCLVII, Tomo I, Madrid, 1973, Década I, Libro I, cap. I, p. 10).

Tenía a don Juan Pacheco, marqués de Villena, que, quando moço pequeño fue paje de don Álvaro de Luna, maestre de Santiago y condestable de Castilla; y después que algún tiempo lo servió, diólo al rrey, quando hera prínçipe. Salió tan discreto y de buen seso, rreposado que para qualquiera devate o contrataçión solía hallar muchos medios. Dava con todas las cosas sanos espedientes, en tal manera que su prudençia hera más probechosa que la de otro ninguno de quantos por entonçes servían. Y asy hallegó a tener gran cavida con el prínçipe, antes que fuese rrey, por donde quedó en gran amor con él. En tanto que por sólo saverse gobernar, por donde suvió a ser marqués de Villena y alcançar rrico casamiento y quando el rrey vino a rreynar, como aquél se avía criado en su casa rreal y lo tenía por honbre de syngular yngenio, quedóse en aquel mesma ser y cavida, que primero tenía, de tal guisa que hera el más prinçipal honbre de su Consejo... y asy el marqués con la prudençia... (Diego Enríquez del Castillo, Crónica de Enrique $I V$. Edición crítica de Aureliano Sánchez Martín, Valladolid, servicio de Publicaciones de la Universidad, 1994, cap. 7, p. 145).

Las fechas que he elegido para enmarcar lo que podríamos definir como el "irresistible" - nunca mejor dicho- ascenso personal de Juan Pacheco a la nobleza de primera fila del reino de Castilla, no son en absoluto caprichosas, ni, por otra parte, lo podrían ser. En el año 1440, la primera de esas fechas mencionadas, este personaje comienza a hacerse presente en el tablero político del reino, para iniciar su propio juego personal que, de forma todavía insegura al principio, le conduciría en poco más de seis años de simple doncel del heredero al trono nada menos que al marquesado de Villena, el gran dominio señorial que, tradicionalmente, había servido como "apanage" para miembros segundones de la familia real ${ }^{1}$. Una fulgurante carrera política para el primogénito de un modesto señor de Belmonte, descendiente por parte materna de grandes aristócratas portugueses caídos en desgracia y exiliados en Castilla tras la guerra de 1397; sorprendente promoción que sólo puede explicarse por dos circunstancias que supo aprovechar con enorme habilidad y astucia en su propio beneficio: por una parte, su privilegiada posición junto al príncipe de Asturias, sobre el que ejercía un completo dominio, y por otra, la compleja coyuntura política en que se desenvolvía el reino castellano entre los años 1440 y 1445, un estado dividido entre dos bandos que pugnaban cada uno a su manera por controlar el poder monárquico; de un lado el que podríamos definir como partido dirigido por el privado del monarca, Álvaro de Luna, que tendría a fortalecer el poder real, siempre desde luego que, a su vez, se incrementase el poder personal del valido, y del otro un conglomerado de intereses presidido por los infantes de Aragón - Juan y Enrique- aliados coyunturalmente con una serie de personajes de la alta nobleza - el Almirante, Benavente y otros-descontentos con el gobierno del condestable. Sobre estas dos bazas, Pacheco logrará construir un tercer partido - vamos a llamarle así- personalizado en el príncipe de Asturias e integrado por todos aquellos que formaban parte de la Casa del heredero, controlados, por lo demás, por el ambicioso e integrante doncel, que va a tener como objetivo conseguir una amplia base de poder económico que le permitiese, mediante el apoyo

${ }^{1}$ Véase a este respecto el interesante trabajo de José Luís PASTOR ZAPATA, Un ejemplo de "apanage" hispánico: El señorío de Villena (1250-1445), "Revista del Instituto de Estudios Alicantinos", 31 (1980), pp. 15-40. 
interesado, según la coyuntura y oportunidad, a uno y otro bando, participar de forma permanente en la toma de decisiones políticas. Como veremos, no le resultará difícil lograrlo. En este sentido, la fecha final que ofrezco, 1445, puede resultar simbólica a este respecto: el camino recorrido desde 1440 ha llegado a una meta, el doncel ha conseguido convertirse en rico hombre y formar parte, por consiguiente, de la alta nobleza del reino. Nunca pudo imaginarse, al comienzo de su aventura, llegar tan lejos y tan alto, nada menos que a marqués de Villena. A partir de ahora todo poder en Castilla, por muy alto que fuese - Juan II, don Álvaro o el rey de Navarra- tendría que contar necesariamente con él, siempre, desde luego, que siguiese controlando la voluntad del heredero, algo que, por otra parte, salvo algún accidente aislado, no le iba a resultar difícil. Además, y como ya tendremos ocasión de referir, la utilización del príncipe Enrique, continuando el juego de poder iniciado en 1440, apoyando en ocasiones a la liga nobiliaria, traicionándola cuando fuese necesario y pasándose al bando del condestable Luna, le iba a permitir apoderarse de más dominios, de nuevos e importantes señoríos, de jugosas rentas cedidas una y otra vez por la Corona y don Álvaro, necesitados ambos de asegurarse la fidelidad del heredero, y así sucesivamente, hasta el final del reinado de Juan II. Una ambición, por consiguiente, que carecía de límites, que parecía también siempre insatisfecha.

Por otra parte, la etapa que se inicia en 1440 y puede darse por concluida en 1445 , la resaltan de manera muy clara los propios contemporáneos a los hechos, los cronistas de aquel tiempo, por lo general bastante bien informados, testigos fidedignos de esos acontecimientos, que nos ofrecen testimonios de interés sobre la persona y las causas que, a su juicio, explican la rápida promoción de Juan Pacheco. He creído oportuno, a este respecto, ofrecer cuatro textos, e insertarlos en la página que precede a este comentario, correspondientes, por lo demás, a cuatro cronistas de aquella época, de muy diferente naturaleza cada uno, pero que sorprendentemente, coinciden sobre el particular: Pacheco comienza a intervenir en la alta política del reino hacia el año 1440 cuando su protector el príncipe de Asturias empieza a dar señales inequívocas de que era preciso contar con él, como nuevo poder emergente, a la hora de decidir cualquier aspecto que afectase a la gobernación del reino. Es indudable que hasta ese año, el futuro marqués de Villena no había llamado la atención de los cronistas del reinado de Juan II. Ninguno de ellos, por tanto, le había mencionado hasta entonces como personaje a tener en cuenta, porque tampoco nadie que tuviese poder hasta ese año había reparado en su existencia. A partir de ahora, Juan Pacheco va a convertirse en una presencia constante en todas, o casi todas, las páginas de los principales acontecimientos que se iban desarrollando en el devenir del reino. Este va a ser, por consiguiente, el tema que vamos a tratar de explicar a lo largo de este trabajo: el ascenso de Juan Pacheco a la más alta nobleza del reino. Ni que decir tiene que para llevar a buen término esta aventura me han sido de utilidad extraordinaria las crónicas de las épocas, además de la bibliografía que de una u otra manera trata de los principales acontecimientos que jalonan el comienzo de la fulgurante carrera de Pacheco hacia la riqueza y el poder, muy en 
especial los diversos trabajos de Suárez Fernández, que para mí continúa siendo el mejor conocedor de la historia política castellana de este periodo. Por último, me ha enriquecido particularmente la documentación inédita procedente del archivo de los duques de Frías - hoy en Toledo- que ha resultado ser absolutamente imprescindible para conocer de manera detallada el camino emprendido por Juan Pacheco para convertirse en señor de vasallos, rentas, posesiones y oficios procedentes de las sucesivas donaciones regias que va acumulando progresivamente, a medida que utiliza al príncipe en cada jugada o acontecimiento que pudiese permitirle hacerse con alguna de esas prebendas.

\section{DE DONCEL A SEÑOR DE UTIEL}

Un "don nadie", que había entrado como paje al servicio de don Álvaro de Luna, muy probablemente, poco antes de la campaña granadina que desembocó en el episodio de la Higueruela, nacido en Belmonte hacia 1419, si hemos de creer al cronista Pérez de Guzmán, que afirma que, al morir en 1474 contaba con cincuenta y cinco años, iba a tener un extraordinario porvenir político a partir de los años centrales del siglo XV, a base de manejar con extraordinaria habilidad y astucia las sucesivas crisis políticas surgidas en el reino castellano entre 1440 y $1445^{2}$. Pacheco, en efecto, era hijo de Alonso Téllez-Girón, un modesto señor rural de Belmonte, señorío éste que gobernaba en nombre de su mujer, María Pacheco, hija del emigrado portugués Juan Fernández Pacheco, con la que había contraído matrimonio en $1415^{3}$. Alonso Téllez-Girón, señor efectivo de Belmonte desde la muerte de su suegro, se esforzaría durante su larga vida por alcanzar una mejor posición social y mayores y más ricos señorios en Castilla. A fin de conseguir sus objetivos, don Alonso apoyó firmemente al partido monárquico que encabezaba don Álvaro de Luna. Más aún, Téllez-Girón se convirtió desde muy pronto en un protegido del condestable que, como ya hemos expuesto en un trabajo anterior, dominaba un extenso conjunto de señorios próximos a la villa de Belmonte $^{4}$. No le quedaba más remedio que formar parte de esa parcialidad si quería seguir sobreviviendo como titular del señorío de su esposa. Así, en 1431 tuvo que participar en la campaña granadina organizada y dirigida por Juan II y Álvaro de Luna, empresa ésta que culminaría en la victoria de la

\footnotetext{
${ }^{2}$ Fernán PÉREZ DE GUZMÁN, Generaciones y semblanzas. Se equivoca, por tanto, Luis Suárez cuando afirma que Pacheco tenía la misma edad que Enrique IV cuando, en realidad, le llevaba seis años. Enrique IV de Castilla, Barcelona, Ariel, 2001, p. 25.

${ }^{3} \mathrm{He}$ estudiado el linaje portugués de los Pacheco hasta su entrada en Castilla en mi trabajo, en colaboración con José Antonio García Luján, Los Pacheco. La imagen mítica de un linaje portugués en tierras de Castilla en "Actas de If Jornadas Luso-espanholas da Historia Medieval", III, Porto, 1989, pp. 943-991. De ese año, 1415, en que María Pacheco y Téllez-Girón contraen matrimonio procede la bula de dispensa pontificia que se encuentra en el Archivo Ducal de Frías (en adelante, ADF), caja $5, n^{\circ} 9$.

${ }^{4}$ Ibídem, p. 971.
} 
Higueruela ${ }^{5}$. A pesar de que se decía de él, con evidente exageración, que era señor de unos 800 vasallos en el obispado de Cuenca, y de que su casa servía al rey con más ochenta lanzas, nunca pasaría de ser un modesto señor rural ni, por supuesto, lograría jamás formar parte de la alta nobleza castellana ${ }^{6}$. No llegaría, pues, a convertirse en gran personaje de la corte, y quizás su linaje hubiese carecido de futuro si de su matrimonio con María Pacheco no hubiesen nacido dos vástagos excepcionales, Juan Pacheco y Pedro Girón. Ambos se criaron como pajes en la casa de don Álvaro de Luna. El primogénito, Juan, adoptó el apellido de su madre para poder heredar la villa de Belmonte; el segundo, Pedro, tomaría el de su padre, Girón. Ambos como veremos, se mantendrían siempre, desde su más tierna edad, muy unidos, y pasarían juntos, por decisión del condestable, a servir como donceles del príncipe heredero, cuando en 1435 el todopoderoso privado de Juan II se hizo cargo por mandato regio de la guarda y custodia del futuro Enrique IV ${ }^{7}$. El mayor, Pacheco, más despierto, más inteligente y, por supuesto, más hábil que el segundo, tuvo tiempo suficiente, mientras sirvió a don Álvaro, y desde luego después, para observar detenidamente la personalidad y el comportamiento del condestable, hasta el punto de tomarlo más adelante como modelo político a imitar. Por aquel entonces, segunda mitad de los años treinta del siglo XV, don Álvaro ignoraba por completo que aquel adolescente, que le había servido en su casa y que ahora colocaba junto al príncipe heredero, terminaría por ser uno de los máximos responsables de su ruina política, aunque no, desde luego, de su ejecución. Entre 1435 y 1440, todavía no había demostrado Pacheco ninguna de sus muchas habilidades, no se sabía aún, al menos el astuto condestable no lo había percibido, el grado tan intenso de afecto que le tenía el futuro Enrique IV. Dos años más tarde, una vez descubierta la personalidad tan mañosa y astuta de su antiguo protegido, don Álvaro había aprendido una nueva y dura lección, propinada por aquel jovenzuelo impertinente y correoso, que había osado desafiarle personalmente al conseguir la nulidad matrimonial de su primera esposa, Angelina de Luna, una prima del condestable con la que le había obligado a casarse por la fuerza unos años antes ${ }^{8}$. Este vínculo matrimonial que ahora, en 1442, se disolvía por voluntad expresa del joven Pacheco, había sido cuidadosamente preparado

${ }^{5}$ Crónica de Juan II, año 1431, cap. XIX, p. 498.

${ }^{6}$ Alfonso Franco y J.A. GARCía LuJÁn, Los Pacheco, p. 971.

7 "Ya en este año (el cronista se refiere a 1440) privaba con el Príncipe Enrique un doncel suyo llamado Juan Pacheco, hijo de Alonso Téllez Giron, Señor de Belmonte, el cual Alvaro de Luna había dejado en la Casa del Príncipe cuando le fue dada la Camarería Mayor del Príncipe"; Crónica de Juan II, año 1440, cap. XIII, p. 565. El nombramiento de don Alvaro como mayordomo mayor del Príncipe en Refundición de la Cróniça del Halconero por el Obispo Lope Barrientos. Ed. y estudio de Juan de Mata Carriazo, Madrid, 1946, cap. CIX p. 196.

${ }^{8}$ Este primer matrimonio de Juan Pacheco ha sido objeto de análisis por mí parte en un trabajo aún inédito, Las mujeres de Juan Pacheco, en vías de publicación. El proceso de nulidad matrimonial con doña Angelina de Luna en ADF, Catálogo Antiguo, leg. 42, $n^{\circ} 2$. Se equivoca Luis Suárez Fernández cuando afirma que en 1442 Pacheco "disolvía los últimos vínculos que le ligaban al condestable al conseguir sentencia de nulidad de su matrimonio con María Portocarrero", Enrique IV de Castilla, E. Ariel, Barcelona, 2001, p. 38; en realidad el ilustre historiador confunde a doña Angelina de Luna, de la que realmente se separa, con la segunda esposa, María Portocarrero, de la que hablaremos más adelante. 
por el privado de Juan II con el objetivo, al enlazar por vía de casamiento con su linaje, de tenerle más controlado, probablemente porque ya observaba con cierta prevención el dominio que ejercía sobre el heredero. Desde ese momento, don Álvaro, que había creído ingenuamente que no se desviaría un punto de sus instrucciones, se daría cuenta amargamente de que ya no podía contar con su antiguo protegido que comenzaba a volar, y de qué modo, por su cuenta. Todavía intentaría en varias ocasiones jugar con él y atraerle a su causa, pero pronto quedaría a su merced, al menos en los años inmediatamente posteriores a la batalla de Olmedo.

Acabo de mencionar un detalle que me parece de gran importancia: la presencia junto a Pacheco, constante y continua, de su hermano menor, Pedro Girón. No hay Girón sin Pacheco y quizas también, aunque no estoy muy cierto, no hay Pacheco sin Girón ${ }^{9}$. Son las dos caras de una misma moneda, como veremos más adelante. Sin su hermano, el marqués de Villena, es casi seguro que Pedro Girón no hubiese sido nunca nada en el reino de Castilla. Pacheco es la persona inteligente, la que piensa, traza los planes, despliega, en suma, una impresionante estrategia política y diplomática que Girón ejecutará sin más dilación. Juan Pacheco, por sí solo, podría haberse abierto camino en el complejo y convulso mundo político de la Castilla del siglo $\mathrm{XV}$, pero con la ayuda de su hermano llegaría a mucho más de lo que podía haber aspirado en los comienzos de su carrera. Uno y otro se ayudarían y se utilizarían mutuamente. En el río revuelto de la política castellana de los años centrales de la centuria decimoquinta, éstos dos hermanos, utilizando a un príncipe débil, al que dominaban casi por completo desde su adolescencia, y a fuerza de desplegar una extraordinaria inteligencia y habilidad, en una coyuntura tan difícil, supieron crear desde la nada dos de los estados señoriales más poderosos del reino de Castilla.

Así pues, es en 1440 cuando Pacheco y su hermano Girón irrumpen con cierta fuerza en el panorama político castellano. Es a partir de este año cuando, como acabo de exponer, los cronistas de Juan II no sólo registran sus nombres sino que también comienzan, con cierta preocupación, a tomarles en consideración. Así, en la crónica de Juan II, en el capítulo correspondiente a 1440 se dice textualmente: ya en este año privaba con el príncipe Enrique un doncel suyo llamado Juan Pacheco, hijo de Alonso Téllez Girón, Señor de Belmonte, al qual Álvaro de Luna había dejado en la casa del Príncipe ${ }^{10}$. El testimonio del halconero del monarca, Pedro Carrillo de Huete, que recojo al comienzo de este trabajo es también sumamente expresivo al respecto ${ }^{11}$. De igual manera, Palencia y Enríquez del Castillo, expresarán la misma opinión $^{12}$. Sin duda alguna esta fecha resulta importante en la vida de Pacheco;

\footnotetext{
${ }^{9}$ Ver a este respecto mi trabajo "Don Pedro Girón, fundador de la Casa de Osuna (14231466)", publicado en mi libro Señores y señoríos, Universidad de Jaén, 1977, pp. 217-260.

${ }^{10}$ Véase nota $\mathrm{n}^{0} 7$.

${ }^{11}$ Crónica del Halconero de Juan II, pp. 342-343.

${ }_{12}^{12}$ Palencia, Crónica de Enrique IV, Libro I, cap. I, p. 10 y Enríquez del Castillo, Crónica de Enrique IV (ed. de Aureliano Sanchez Martín), p. 145.
} 
además el propio protagonista fue muy consciente de que su carrera política se había iniciado en ese año concreto, pues en su testamento de 1470 así lo reconoce: Item, por quanto yo tengo cargo de algunas cosas que yo tomé e leué de algunas personas, e asymesmo tengo cargo de algunos daños que yo fize, asý por mi como por mis gentes en las guerras e debates e movimientos pasados desde el año que pasó de quarenta fasta agora ${ }^{13}$. Con un trabajo paciente y tenaz, ambos hermanos habían logrado, a lo largo de los cinco años anteriores, dominar la voluntad del príncipe heredero y, a través de toda clase de manejos y procedimientos de los que, con evidente maldad y exageración, se hace eco el cronista Palencia, consiguieron convertirse en personas indispensables para el futuro rey ${ }^{14}$. Sea de ello lo que fuere, el hecho cierto es que desde ese año, como muy bien afirma el profesor Suárez Fernández, el mayor de los hermanos, que aspiraba a desempeñar junto al hijo el mismo papel que don Álvaro seguía ejerciendo junto al padre, pasa a ser la "estrella ascendente" del reino, con un primer objetivo bien concreto: lograr la independencia económica de su amo, porque sólo de esa forma el peso del heredero en la política podría llegar a ser decisivo ${ }^{15}$.

De esta manera, y a riesgo de cierta reiteración que juzgo necesaria, el príncipe de Asturias comienza a intervenir en la vida política del reino, exigiendo su propia cuota en la toma de decisiones políticas. En la sombra, todavía se encuentra Juan Pacheco y, tras él, su hermano Pedro Girón. En estos primeros años ambos hermanos comienzan a recibir modestas donaciones, todavía de oficios cortesanos y de villas concedidas por el príncipe o por el propio monarca, a petición de su hijo, que tienen como finalidad fortalecer el poder político de don Enrique y, sobre todo, la posición económica de sus dos servidores, que tratan por todos los medios a su alcance de mantener y conservar la privanza junto al heredero. Estas maquinaciones no pasaron desapercibidas para Carrillo de Huete, el siempre informado halconero de Juan II, que ya en 1440 advertía al lector de lo que estaba sucediendo ${ }^{16}$ :

Este Príncipe don Enrique, desque pasó de hedad 18 años, quiso ser mucho ensí, e fazer mucho de lo que él quería, e arredrarse de la corte a su tierra, en espeçial a la çibdad de Segobia, que era suya, a correr monte e caça e tomar plazer en ella. Este Prínçipe tenía vn donzel que llamaban Pacheco, susoscripto, al qual amaba este Príncipe muy mucho, tanto que no se fazía cosa en su casa que lo más no se fiziese como este Pacheco quería.

\footnotetext{
${ }^{13}$ Alfonso Franco Silva, El señorio Toledano de Montalbán. De Don Álvaro de Luna a los Pacheco, Cádiz, 1992, p. 204.

${ }^{14}$ Crónica de Enrique IV, Libro I, cap. I, p. 9. Palencia dice a este respecto lo siguiente: "No sin sospecha de algún trato indecoroso y de lascivas complacencias por parte del Privado en su familiaridad con el Rey". Y más adelante (cap. X, p. 30) dice de Girón que era "bien quisto del Príncipe por quanto más descaradamente que los otros, se entregaba a un desenfreno muy conforme con sus gustos, $\mathrm{y}$ tal que sonroja y apena referir por que clase de méritos y por qué grados fue subiendo a la más alta privanza”.

${ }^{15}$ Luis SuÁREZ FERNÁNDEZ, Los Trastámaras de Castilla y Aragón en el siglo XV, en Historia de España dirigida por D. Ramón Menéndez Pidal, Tomo XV, Madrid, 1982, p. 174; y del mismo autor su obra Nobleza y Monarquía. Puntos de vista sobre la historia politica castellana del siglo XV, Valladolid, 1959, p. 115 .

${ }^{16}$ Crónica del Halconero, cap. CCLXXXIII, p. 356.
} 
En este dúo de ambiciosos la personalidad de Juan Pacheco se destacaba sobre la de su hermano, sin que ello quiera decir que el futuro Enrique IV tuviese menos afecto por este último. En este verdadero intercambio de papeles, Pacheco es sagaz, diestro y astuto, como le llama el cronista Palencia, más inteligente, más político, en suma quien se lleva la mejor parte ${ }^{17}$. Es el hermano mayor quien dirige verdaderamente la casa y la persona del príncipe, es a él a quien se dirigen Juan II y su esposa, la reina María, en su correspondencia, cuando querían tener noticias sobre su hijo y le dan recomendaciones al respecto, es, en definitiva, el privado ${ }^{18}$. Su hermano le era indispensable para controlar por completo la persona del príncipe, pues éste, según Palencia, le tenía enorme afecto; le ayudaría mucho, como ya veremos, en aquellos asuntos que a Pacheco le interesaban menos o para los que no se encontraba bien dotado ${ }^{19}$.

Cuando Pacheco y su hermano comienzan a intervenir en la política del reino, don Álvaro de Luna había sido desterrado de la corte, un año antes, tras la conferencia de Castronuño, por la acción combinada de los infantes de Aragón, Juan y Enrique, y una liga de nobles hostiles a la política del condestable, entre los que figuraban don Fadrique, el adelantado Pedro Manrique y los Estúñiga ${ }^{20}$. El privado de Juan II abandonaba el poder, pero dejaba a sus hombres de confianza en el Consejo Real, que, según los nobles desafectos, constituía el verdadero órgano del gobierno. Este hecho le permitió pensar en un pronto retorno a la corte, y de hecho, poco después de ser desterrado, en los meses finales de 1439 y en los primeros del año siguiente, trataría por todos los medios a su alcance de separar a los infantes del grupo nobiliario con el que se habían aliado. Sus tentativas resultarían infructuosas, sobre todo tras la huida de Juan II de la corte, en enero de 1440. La fuga del monarca, presentada por los infantes como una muestra más de que el rey no aceptaba el programa de la oligarquía nobiliaria, impuesto en Castronuño, sería contraproducente para la monarquía porque, fue entonces,

\footnotetext{
${ }^{17}$ Alfonso Franco Silva, Don Pedro Girón, en Señores y señoríos, p. 225.

${ }^{18}$ Ibídem, p. 225. Pueden servir como modelo los ejemplos siguientes. El 24 de enero de 1442, la reina doña Ṃaría dirigió a Pacheco una carta en que le pedía que intercediese ante el príncipe para que pusiese en libertad a su doncel Lope de Piña, a quien había hecho prender por ciertas acusaciones de "malas gentes" de la villa de Molina de Aragón, quienes afirmaban que el tal doncel había cometido algunos delitos e insultos en la época en que esa villa pertenecía a la reina (ADF, Catálogo Antiguo, Leg. 56). El 24 de julio de ese mismo año, desde Valladolid, era el propio monarca quien pedía a Pacheco que recomendase a un boticario, Gonzalo Ruiz de Segovia, a quien las monjas de Santa Clara querían hacer desalojar de una casa que tenía arrendada a censo (ADF, C̣atálogo Antiguo, leg. 56). Tres meses más tarde, Juan II volvía a dirigirse al privado de su hijo desde la villa de Arrévalo para que procurase que el príncipe no le privase al comendador Juan Alfón de Nova de su oficio de tesorero (ADF, Catálogo Antiguo, leg. $\left.56, n^{\circ} 7\right)$. Finalmente, un año más tarde, en abril, era de nuevo la reina quien escribía a Pacheco para que intercediese ante su hijo a fin de que dejase cobrar cierta suma de maravedíes a Ruy Diaz de Mendoza que debía recibir en El Espinar (ADF, Catálogo Antiguo, Leg. 56, n 11).

${ }^{19}$ Ibídem, p. 225.

${ }^{20}$ Luis SUÁREZ FernÁNDEZ, Los Trastámaras, en Historia de España, dirigida por Menéndez Pidal, pp. 152-158.
} 
según Suárez Fernández, cuando toda la nobleza se inclinó decididamente por los hijos de Fernando de Antequera ${ }^{21}$.

Fue precisamente en esos momentos, entre marzo y septiembre de 1440 , en pleno triunfo de los infantes y de la nobleza, cuando aparecen nuevos personajes en escena. Me refiero naturalmente al príncipe Enrique y a sus dos acólitos, que comenzaron a exigir una parte del pastel a repartir. En principio podía suponerse que el heredero del trono, precisamente por serlo, seguiría desde su condición de sucesor la opinión del padre, es decir se encontraría al lado del monarca. Y así fue, al menos de momento, entre otras razones porque, para Pacheco, sólo el monarca podía conceder al príncipe una base económica lo suficientemente estable como para conseguir una cierta autonomía que le permitiese maniobrar a su entera conveniencia entre ambos bandos, el que había triunfado ahora encabezado por los infantes de Aragón, y el del condestable, coyunturalmente derrotado pero que no había perdido la esperanza de retornar al gobierno, ya que continuaba teniendo el apoyo de Juan II. En principio, Pacheco logró que el monarca le otorgase promesa solemne de defenderle, tanto a él como a su padre, Alonso Téllez-Girón, no sólo en cuanto a sus personas sino también en lo que se refería a sus bienes - esto es, el señorío de Belmonte- ${ }^{22}$. El rey, además, y esto era también de vital importancia para el interesado, le aseguraba que jamás le privaría de los oficios que desempeñaba en la casa del príncipe. La razón que explica la existencia de este interesantísimo documento se encuentra en el temor que Pacheco sentía hacia el posible regreso de don Álvaro y, al mismo tiempo, la necesidad de protección frente a los infantes de Aragón que ahora se hallaban en el poder. De esta manera nada podía temer, protegido como estaba por el seguro real. Es más, podía ahora tomar decisiones sin problema alguno, todas aquellas que afectasen a la promoción del príncipe y qué duda cabe, a la suya propia, ya que era el poder regio, y no don Álvaro como había sucedido hasta entonces, quien se había comprometido a mantenerle en el puesto de consejero de su hijo. Pacheco, por su parte, le prometía al monarca que le sería fiel y, sobre todo, que se ocuparía personalmente de que el príncipe continuase, siempre y en todo momento, bajo la obediencia paterna. Falsa promesa, la primera de las muchas que a lo largo de su agitada vida haría Juan Pacheco, como se verá de inmediato. No importaba; al futuro marqués de Villena sólo le interesaba su propia promoción personal, aunque para ello hubiese que prestar los juramentos que fuesen necesarios, se hiciesen sobre las sagradas escrituras o sobre la señal de la cruz, o incluso bajo palabra de caballero con pleito-homenaje, y todas las formalidades y simbolismos habidos y por haber. En este sentido, Pacheco va a ser un político nato, sin ningún tipo de escrúpulos ni respeto a la palabra dada bajo juramento, atento sólo a su beneficio personal, ajeno por completo a los usos y costumbres de la sociedad feudal y caballeresca de su tiempo, aunque formalmente los respetase, pero

\footnotetext{
${ }^{21}$ Ibídem, p. 160.

${ }^{22}$ Este interesante documento en ADF, Catálogo Antiguo, leg. 56, $\mathrm{n}^{\circ} 6$.
} 
siempre, eso sí, sin ánimo de cumplirlos. Lo vamos a comprobar en las páginas que siguen. Casi con toda seguridad, el juramento que en octubre de 1440 presta al monarca era el primero que hacía en su vida y, como todos los demás que haría posteriormente, sólo lo respetaría mientras que le trajesen honores, señoríos y rentas. Si se había prestado a ello lo había hecho por las razones ya mencionadas, que para él eran de suma importancia, y también, porque en ese mismo documento, Juan II le prometía, bajo palabra de caballero, que si alguno de sus cargos y honores le fuesen confiscados, le daría justa compensación por ellos.

El mismo día en que obtenía la promesa de seguro real para su persona, el 26 de octubre de 1440, Juan Pacheco lograba convertirse en señor de tierras y vasallos. En efecto, una cédula despachada por el monarca en ese día concedía licencia a su hijo el príncipe Enrique para que pudiese donar a su doncel los lugares de Villanueva de Alcaraz, el Bonillo, Lozuza y Munera, que previamente habían sido apartadas de la jurisdicción de Alcaraz, villa de la que habían formado parte hasta entonces, a fin de que pudiese gozar de todas sus rentas, excepto alcabalas y mineros de oro que, como en toda concesión regia, la Corona reservaba para $\mathrm{sí}^{23}$. No era, sin embargo, la primera prebenda que recibía; unos meses antes, en marzo de ese mismo año, Juan II le concedía un oficio de carácter doméstico: la trichantía o cuchillo de la mesa del príncipe, con la cantidad de 300 maravedíes de ración al día ${ }^{24}$. Al mes siguiente, Pacheco recibía nuevos honores, nada menos que los oficios de la justicia civil y criminal de Segovia y su tierra, así de las alcaldías como de los alguacilazgos, a fin de que pudiese poner en la ciudad y su tierra corregidor, alcaldes, jueces etc ${ }^{25}$. La concesión de estos oficios era vitalicia pero no hereditaria. Esta última donación no la hacía el monarca sino el príncipe Enrique. Es muy posible que se trate del primer documento emitido por el futuro monarca que se intitulaba príncipe de Asturias y señor de las ciudades de Segovia, Trujillo y Alcaraz, que su padre le había concedido muy poco antes.

¿Qué había detrás de estas primeras donaciones? ¿A qué motivaciones obedecían? Significativamente, el doncel de don Enrique recibía oficios en Segovia, y al mismo tiempo la jurisdicción sobre cuatro lugares que habían formado parte de Alcaraz. Ya sabemos que el príncipe se intitulaba señor de Segovia y de Alcaraz. La respuesta, por tanto, a la pregunta que hemos formulado no puede ser más clara: Pacheco recibía prebendas procedentes de aquellas ciudades - Segovia y Alcaraz - que le habían sido donadas a don

\footnotetext{
${ }^{23} \mathrm{ADF}$, Catálogo Antiguo, Leg. 3, números 3 y 4. El 31 de octubre de ese mismo año, Pedro Trujillo recibió órdenes de Pacheco para que tomase posesión de Utiel y de los cuatro lugares citados. La toma de posesión se retrasó hasta diciembre de ese año debido a la resistencia que opuso Álcaraz a la entrega de esos lugares que le arrebataban sin ningún tipo de compensación; ver a este respecto el documento del ADF, Catálogo Antiguo, Leg. 56, n⿳⺈ ${ }^{\circ}$.

${ }^{24} \mathrm{ADF}$, Catálogo Antiguo, Leg. $3 \mathrm{n}^{\mathbf{0}} 1$. Advierto al lector que estoy utilizando las signaturas del catálogo de Pilar LEON TELLO, Inventario del Archivo de los duques de Frias, II, Madrid, 1967.

${ }^{25} \mathrm{ADF}$, Catálogo Antiguo, Leg. $3, \mathrm{n}^{0} 2$.
} 
Enrique por su padre "como parte del programa de crecimiento de la Casa de príncipe, aunque no se juzgó necesario todavía la concesión del Principado de Asturias"26. De esta manera, el primer cargo importante de Pacheco fue precisamente, a juicio de Suárez Fernández, "el mando de la guarnición segoviana, lo que le permitió descubrir la importancia del alcázar para cualquier maniobra política"27. Yo añadiría también que si esta última donación tenía para Pacheco especial significado, no lo es menos la concesión de las aldeas de Alcaraz, que le permitían convertirse por vez primera en señor de vasallos, nada menos que en número total de 500, que sumaban juntos los cuatro lugares ya mencionados. Aún más: en esa misma cédula el futuro marqués de Villena recibía otro señorío, el que más deseaba desde hacía algún tiempo, la villa de Utiel con una población que se estimaba en torno a los 300 vecinos, villa ésta que, por otra parte, el propio Juan II había prometido solemnemente unos años antes que jamás sería enajenada de la Corona $^{28}$. Utiel pertenecía a la jurisdicción de Alcaraz, y por tanto formaba parte de los dominios concedidos al príncipe de Asturias. Antes de ser donada a Pacheco, dos días después de la concesión real a don Enrique, fue previamente segregada de la jurisdicción de Alcaraz que, de esta manera, perdía, junto con Lozuza, Munera, El Bonillo y Villanueva una gran parte de su antiguo y extenso alfoz. Pero si Pacheco pudo fácilmente, tras cierta resistencia inicial por parte del concejo de Alcaraz, hacerse con esos cuatro lugares, que de inmediato puso bajo el gobierno de su padre, Alonso TéllezGirón, pues él se hallaba plenamente inmerso en la política del reino, no le fue posible, en cambio, tomar posesión de la villa de Utiel hasta tres años después. En efecto, nada más recibir la donación de la villa, Pacheco dio poder a Pedro de Trujillo, repostero de camas del príncipe, para que tomase posesión de ella y de los cuatro lugares que habían pertenecido a la jurisdicción de Alcaraz ${ }^{29}$. No hubo problemas con estos últimos, pero sí con Utiel que se negó a ser enajenada del realengo. El concejo de la villa no aceptó a Pacheco como señor, ni sus vecinos "quisieron resçebir la justiçia que el sennor prinçipe a la dicha villa enbiaua". Un año más tarde, el joven Pacheco, en buenas cuentas por entonces con los infantes de Aragón, como veremos, utilizó los oficios de Juan de Navarra y de su hermano Enrique -que llegó a ofrecerle incluso la ayuda de los dominios santiaguistas que su orden tenía en el reino de Murcia- para tomar posesión definitiva de la villa ${ }^{30}$. Juan de Navarra llegó incluso a enviar a tal efecto a su criado Lope de Alarcón, pero

\footnotetext{
${ }^{26}$ Luis SUÁREZ FERNÁNDEZ, Enrique IV de Castilla, p. 24.

${ }^{27}$ Ibídem, p. 24.

${ }^{28}$ La donación de Utiel en ADF, Catálogo Antiguo, leg. 3, n ${ }^{\circ}$ 2. Utiel había pertenecido a los dominios de don Juan de Albornoz. Tras el fallecimiento de este personaje, su viuda, doña Constanza, en nombre de sus hijas María y Beatriz, vendió la villa al propio concejo de Utiel por 8.000 florines, cantidad ésta que necesitaba para pagar las deudas y descargos de conciencia de su esposo, ya que este no había dejado bienes muebles para satisfacer esas mandas. La villa había obtenido privilegio de Juan I, Enrique III y Juan II a fin de no ser enajenada de la Corona. ADF, caja $2 \mathrm{n}^{\circ} 2$.

${ }^{29} \mathrm{ADF}$, caja $2, \mathrm{n}^{\circ} 4$.

${ }^{30} \mathrm{ADF}$, caja $2, \mathrm{n}^{0} 5$.
} 
tampoco obtuvo resultado alguno. Unos días después era Pacheco quien mandaba a su criado, Pero Coello, señor de Montalus, para que intentase reducir a la obediencia a sus vasallos de Utiel ${ }^{31}$. El propio monarca decidió también intervenir, azuzado, quizás por su hijo, y a tal fin envió por su parte a Fernán Vázquez de Acuña y a Rodrigo Pacheco, vecinos de Alarcón, para que obligaran al concejo de Utiel a entregarse a Juan Pacheco ${ }^{32}$. Ninguna de estas medidas surtió efecto, la villa continuó oponiéndose a entrar en señorío. $\mathrm{Al}$ año siguiente, la situación continuaba en parecidos términos, pues en marzo el príncipe Enrique ordenaba a los vecinos de Moya que tratasen de ayudar a Juan Pacheco en sus reiterados intentos por tomar posesión de Utiel $^{33}$. En esta última cédula, despachada desde Tordesillas, el heredero del trono describía la revuelta de la villa en estos términos: los vecinos de Utiel no querían recibir a Pacheco como señor porque el concejo de Moya les estaba prestando ayuda, e incluso habían rechazado la hueste que don Enrique había enviado para reducir la villa. Don Enrique amenazó a los vecinos de Moya con castigarles duramente si no obedecían su mandato. A pesar de todo, la revuelta no cesaría, y hubo necesidad de recurrir de nuevo al monarca. Juan II desde Valladolid, el 10 de abril de 1442, envió una provisión y sobrecarta al concejo de Utiel, que hasta entonces no había hecho caso del mandato del príncipe ni del suyo, para que de una vez por todas cesasen en su rebeldía y se entregasen a su señor, bajo la amenaza de severas penas si no obedecían sus órdenes ${ }^{34}$. La negativa de Utiel a pasar del realengo al señorío continuó, sin embargo, al amparo sin duda de la situación política del reino, y de nada sirvieron los mandatos reales y principescos para reducirla. Dos años habían pasado y la situación seguía siendo la misma. Tampoco hizo efecto una tercera provisión del príncipe Enrique redactada en idénticos términos que las anteriores, enviada esta vez desde Segovia el 29 de agosto de $1442^{35}$. El hecho parecía verdaderamente insólito y, desde luego, la desobediencia de Utiel se tornaba cada vez más peligrosa para los intereses de sus vecinos. Tres años y la revuelta proseguía. Finalmente, el concejo no tuvo más remedio que ceder. Una nueva y última provisión del heredero del trono, despachada desde Tordesillas el 12 de julio de 1443, hizo reflexionar a la oligarquía que dominaba el cabildo municipal de la villa ${ }^{36}$. El futuro Enrique IV enviaba a su alcalde mayor, Diego Muñoz de Belmonte - un paniaguado de Pacheco- para que se dirigiese a Utiel y a la mayor brevedad posible, utilizando los procedimientos que estimase oportunos, tomase posesión de la villa en nombre de su protegido. El príncipe, así mismo, le encargaba que pusiese en poder de Pacheco los castillos de Argal, Mochales, Castilnovo y Torre de Aragón, que

\footnotetext{
${ }^{31} \mathrm{ADF}$, caja $2, \mathrm{n}^{\mathrm{o}} 7$.

${ }^{32} \mathrm{ADF}$, caja $2, \mathrm{n}^{\circ} 8$.

${ }^{33} \mathrm{ADF}$, caja $2, \mathrm{n}^{\circ} 9$.

${ }^{34} \mathrm{ADF}$, caja $2, \mathrm{n}^{\mathrm{o}} 10$.

${ }^{35} \mathrm{ADF}$, caja $2, \mathrm{n}^{\mathrm{o}} 11$

${ }^{36} \mathrm{ADF}$, caja $2, \mathrm{n}^{\circ} 14$.
} 
hasta ese momento habían formado parte de la jurisdicción de la villa de Molina de Aragón, y que le había donado poco antes en compensación por la negativa de Utiel a reducirse a su servicio. Diego Muñoz de Belmonte no se desplazaba solo, le acompañaba una nutrida hueste armada por el heredero del trono para ocupar la villa por la fuerza si era necesario, "e les sujetase haçiéndoles guerra" si se atrevían a negarle entrada, "talándoles, en ese caso viñas e llevándoles ganados, panes, bestias e bienes, e talando casas e matando e feriendo o perdonando a aquellos vecinos que se acogiesen a su mandamiento". Al parecer, también esos castillos se habían rebelado cuando se supo que el príncipe, que acababa de recibir de su padre la villa de Molina, había concedido su tenencia a Pacheco. La cédula del príncipe va fechada el 12 de julio, pues bien, todavía el 23 de agosto, un mes después, la villa no se había entregado al enviado de don Enrique, pues en esa última fecha el heredero se vió obligado a cursar una orden a los vecinos de Moya para que declarasen la guerra a los de Utiel que no terminaban por rendirse ${ }^{37}$. La situación era tan grave y tan insólita para la época, que don Enrique exigía al concejo de Moya que todos los vecinos que se encontrasen entre los dieciocho y los sesenta años tomasen las armas y se dirigiesen contra los de Utiel para ayudar a su alcalde mayor a sofocar la revuelta de la villa, ya que, de no hacerlo, se expondrían a perder todos sus privilegios y a la confiscación de sus bienes. Dos días más tarde, la villa se rindió a las tropas reales, tras una ardua negociación en la que Pacheco se vió obligado a firmar un pacto con la oligarquía rebelde. En efecto, el concejo aceptaba como señor a Juan Pacheco, con la condición de entregarle cada año en dos plazos la cantidad de 30.000 maravedíes como reconocimiento de señorío y en concepto de servicio, pedido y martiniega; a cambio se comprometía a respetar a sus nuevos vasallos todos los privilegios y libertades que poseían y disfrutaban desde tiempo inmemorial ${ }^{38}$.

La oposición del concejo de Utiel a entrar en señorío fue el primero, pero también el único contratiempo que el joven Pacheco tendría en los años iniciales de su carrera. Tres años había tardado en hacerse con la villa pero, en conjunto, podía sentirse satisfecho. Partiendo de la nada, con sólo veintiún años - si seguimos aceptando la fecha de 1419 como la más probable de su nacimiento- - y merced a haberse ganado la confianza del príncipe, recibía un total de 800 vasallos que habitaban en la villa de Utiel y en los lugares ya citados. No iba a conformarse sin embargo, antes bien estas donaciones representaban el primer paso de un plan meticulosamente trazado: construirse un gran edificio señorial en tierras de la Mancha, ampliando la posesión inicial heredada de su madre, la villa de Belmonte, y quizá, por qué no, reconstruir en su provecho el antiguo marquesado de Villena. Esta última empresa, si bien podía encontrarse ya en sus planes iniciales, estaba aún muy lejos de conseguirla, porque las tierras del marquesado se hallaban bajo el

\footnotetext{
${ }^{37} \mathrm{ADF}$, caja $2, \mathrm{n}^{0} 15$.

${ }^{38} \mathrm{ADF}$, Catálogo Antiguo, Leg. 3, números 14 y 15.
} 
poder de un personaje muy poderoso, el infante don Enrique de Aragón, al que Pacheco difícilmente, al menos por aquellos años, podía aspirar a derrotar. No había prisa, sin embargo, y sí mucha paciencia y astucia para alcanzar sus objetivos. Su habilidad y la coyuntura política de aquella época le iban a permitir realizar todos sus deseos, utilizando al príncipe Enrique para satisfacer sus ambiciones personales, en el complejo laberinto político del reino castellano. Aquí va a estar la clave que explique el encumbramiento de este hijo de emigrados portugueses.

Por de pronto poseía ya Utiel y los cuatro lugares citados que podían permitirle en el momento preciso hincarle el diente a la importante ciudad de Alcaraz, aunque, en este caso, y por más que lo intentó no lograría conseguir apoderarse de esa ciudad murciana. Estas primeras donaciones habían sido sólo el resultado de la primera intriga protagonizada por Pacheco cuando la corte se había desplazado a Valladolid, a comienzos del verano de 1440, para celebrar las Cortes previstas ya desde varios meses antes. Pues bien, fue por entonces cuando el heredero de Juan II registra la primera de una larga serie de desavenencias con su padre. Don Enrique, tras su boda con Blanca de Navarra, se había inclinado decisivamente por el bando que representaba su suegro, el rey de Navarra. La influencia de éste último sobre su yerno se hizo notar de inmediato. Así, sin mediar causa alguna, don Enrique abandonó la corte y se refugió en la posada del almirante, firme partidario de los infantes de Aragón. Allí le hizo saber a su padre que no regresaría hasta que no expulsase del Consejo Real a los hombres que seguían el partido del condestable: el doctor Pero Yáñez, el contador mayor Alfonso Pérez de Vivero y el maestresala Nicolás Fernández de Villamizar. El halconero, testigo directo de aquella primera escapada del príncipe, relata el acontecimiento de esta manera ${ }^{39}$ :

Por quanto entendía que complía asy al su seruicio, por que veía que
andaban ciertos honbres de su Consejo consejando algunas cosas que non
conplían al su seruicio, ni a pro e vien de sus rreynos, los quales eran el
doctor Periáñes, e Alfonso Pérez de Vibero, su contador mayor, e Nicolás
Fernández de Villamizar, maestresala del rey. E que le pedía por merced
que los mandase yr de su corte, e que faría lo que mandase.

El príncipe, tras manifestar su oposición a que estos tres personajes permaneciesen en el Consejo Real, se declaró dispuesto a regresar al lado del monarca, su padre. Así lo haría poco después, pero para ello fue necesario que el rey de Navarra actuase como mediador, desplazándose incluso a la posada del almirante a fin de convencer a don Enrique de que volviese a la corte. El rey no tuvo más remedio que aceptar las condiciones de su hijo y, en consecuencia, expulsar de la corte a los tres paniaguados de don Álvaro. Al parecer, Pacheco, no fue ajeno a esta primera intervención del príncipe en

${ }^{39}$ Crónica del Halconero, cap. CCLXIX, p. 341. Una versión prácticamente idéntica de este acontecimiento en Crónica de Juan II, año 1440, cap. XIII, p. 564. 
los asuntos del reino. El halconero Carrillo así lo da a entender no sin manifestar cierta preocupación ${ }^{40}$ :

Esto lo hizo el Prínçipe por consejo de algunos... por tener al rey más a su voluntad... E de aquí fue el Príncipe ynduzido que dende en adelante procurase posada aparte del Rey, su padre, lo qual se fizo, e dello de otras cosas semejantes se causaba de cada día apartamiento de las voluntades, e mal para los que tal causaban entre padre e hijo, que aunque al presente parescan prosperar más verdaderamente se pueden dezir caer.

El príncipe, sin embargo, tras este incidente, regresaría, por consejo de su preceptor, el obispo Barrientos, a la obediencia real. De nuevo es Juan Pacheco quien le inclina hacia su padre con la esperanza de obtener buena recompensa. Esta, como hemos visto en páginas anteriores, no tardaría en llegar: el seguro prometido por Juan II y la donación de Utiel y de los cuatro lugares pertenecientes a la villa de Alcaraz. Las maniobras de Pacheco no pasaron desapercibidas para el halconero ${ }^{41}$ :

Tornóse el Príncipe a la ovediencia del Rey su padre, mediente Juan Pacheco su criado e su pribado. El qual, según la spiriençia lo mostrava... le desviaba de la opinión e obediencia del señor Rey su padre, e él mesmo lo tornaba a reconciliar. E esto fazía quando quería sacar del Rey algunas gruesas dádibas e mercedes.

Las intrigas de Juan Pacheco a lo largo de estos seis años, enfrentando al príncipe con los infantes y la nobleza, reconciliándose con el monarca y con don Álvaro, o poniéndolo en contra de estos últimos para apoyar a los primeros, le permitían obtener pingües ganancias, hasta el punto de que el propio Carrillo de Huete llega a decir lo siguiente ${ }^{42}$ :

E por esta vía e con esta plática sacó e alcançó tanto, que en spacio de seys años, dando cada año vna vuelta, llegó a ser marqués e señor del marquesado de Villena, e señor de otras gruesas villas e logares, e de otros muchos heredamientos e mercedes, asy de juro como de por vida. E asy mesmo por esta vía ovo, contra toda justiçia, el maestradgo de Calatrava para su hermano Pedro Girón.

A lo largo del año 1440, los infantes de Aragón habían logrado controlar el poder en Castilla con la ayuda de la liga nobiliaria y la complicidad del príncipe Enrique. Sin embargo, este último, teledirigido siempre por su privado, comenzó al año siguiente a dar muestras de cierta independencia con respecto al bando que encabezaba su suegro. En efecto, don Álvaro de Luna, apoyado por el monarca, que estaba decidido a deshacerse de la presión que sobre él ejercían sus primos, comenzó a elaborar planes para retornar a la corte, y a tal fin inició sus preparativos para enfrentarse a sus enemigos por

\footnotetext{
${ }^{40}$ Ibídem, p. 342.

${ }^{41}$ Ibídem, pp. 34-343.

${ }^{42}$ Ibídem.
} 
las armas si era necesario ${ }^{43}$. A mediados del mes de enero de 1441 se preveía un enfrentamiento armado entre ambos bandos, pero fue entonces cuando el príncipe, desobedeciendo el mandato paterno de reconquistar la villa de Guadalajara, decidió permanecer en su ciudad de Segovia y declararse neutral ${ }^{44}$. Pronto, sin embargo, volvió a sumarse a la facción nobiliaria. No fue ajena a este hecho la influencia de su madre, la reina María, que trataba por todos los medios a su alcance de que su hijo se inclinase más decididamente por el bando de los infantes. Tras una serie de vicisitudes, que narra con todo detalle el profesor Suárez Fernández, y en las que el príncipe intentó jugar un papel de mediador entre ambos bandos, en lucha abierta, don Álvaro se vió obligado a retirarse de nuevo y el rey se puso en manos de la facción vencedora, los infantes y la liga nobiliaria ${ }^{45}$. El resultado de esta cruenta pugna significó también nuevas prebendas para Juan Pacheco, como recompensa por haber mantenido al príncipe próximo a su suegro, el rey de Navarra. Así, el 2 de septiembre de 1441, Juan II se ve obligado, a petición del príncipe y de Juan de Navarra, a introducirle en el Consejo Real, y unos días más tarde don Enrique le concedía la heredad llamada casa-palacio de Bernuy, que se hallaba en el término de la ciudad de Segovia, y todas las tierras, viñas, árboles, huertas, bueyes y otras pertenencias que había en ella $^{46}$. Poco después, el 2 de octubre de ese año, Pacheco recibía otra donación de su protector, en este caso era nada menos que la tenencia de los alcázares de Segovia, "los quales oy dia tenedes con todas las armas, pertrechos e bastimentos que en ellos e fuera dellos están, junto con el salario de la tenencia" ${ }^{47}$. La concesión era vitalicia y comprendía, además, otra vida, la del hijo mayor legítimo del beneficiado. De inmediato, y a instancias de su privado, el príncipe se comprometió, bajo juramento y pleito-homenaje en manos de su montero mayor Esteban Pacheco, a no quitarle jamás esta merced que hasta entonces había disfrutado Ruy Diaz de Mendoza, mayordomo mayor de Juan II.

Así pues, en tan solo dos años, Juan Pacheco había conseguido penetrar en el Consejo Real, órgano supremo de gobierno de la monarquía, y apoderarse, además, de las llaves de Segovia, una de las más importantes ciudades del reino, señorío y residencia principal de su protector, el príncipe. No estaba mal para un joven casi desconocido en la alta sociedad castellana.

\footnotetext{
${ }^{43}$ Los infantes, el almirante y los demás nobles escribieron una carta al monarca, "tomando al príncipe por caveça", en la que le hacían saber que se constituían en enemigos declarados de don Alvaro de Luna "por todos los males que había causado al reino su gobierno tiránico" Crónica del Halconero, cap. CCLXXXIV, p. 357. La Crónica de Juan II también dice que los infantes y la liga nobiliaria tuvieron al príncipe "por cabeza para sus hechos". Cap. XXII, p. 569. Ver a este respecto Luis SUÁREZ FERNÁNDEZ, Los Trastámaras, cit. p. $16 \dot{4}$.

${ }^{44} \mathrm{La}$ entrada en Guadalajara se la negó al príncipe el señor de Hita y Buitrago, Iñigo López de Mendoza, futuro marqués de Santillana, humillación ésta que don Enrique no perdonaría jamás a los Mendoza (Crónica del Halconero, cap. CCLXXXVII, p. 367); los intentos por recobrar Guadalajara, villa ésta que al príncipe le habia sido concedida por su padre en cap. CXC, p. 375.

Véase Luis ŚUÁREZ FERNÁNDEZ, Los Trastámaras, p. 165.

${ }^{45}$ Ibídem, pp. 164 - 171, en especial esta última.

${ }^{46} \mathrm{ADF}$, Catálogo Antiguo, Leg. 3. números 5 y 6.

${ }^{47} \mathrm{ADF}$, Catálogo Antiguo, leg. 3, números 7, 8 y 11.
} 
La cadena de donaciones no se detendrá, sin embargo, antes bien irá en progresivo aumento hasta alcanzar la gran merced del marquesado tras la batalla de Olmedo. Pronto, los nobles comenzarán a sospechar de las verdaderas intenciones del aspirante a privado del heredero al trono. Los cronistas, por su parte, se hicieron eco de una promoción tan fulgurante y empezaron a temer, con fundades razones, que, tras esta fachada, se escondía tan solo la sustitución de un tirano por otro. Así lo expresa el halconero con estas proféticas palabras ${ }^{48}$ :

\begin{abstract}
A tanto que pesaba dello mucho a los grandes del rreyno, reçelando que dello se siguiría en el rreyno lo que otras vezes se avía siguido por causa de algunos pribados, e non por regir los reyes sus rreynos con acuerdo de los del su Consejo. E tanto lugar dio el Principe a este Juan Pacheco, que por causa de alcançar estado desvió al Principe del camino de su padre, e llególo a la opinión del rrey de Navarra e ynfante; por lo qual tomaron mayor osadía de oponerse contra el Rey e contra el Condestable.
\end{abstract}

Al comenzar el año 1442, los infantes de Aragón, sobre todo Juan de Navarra, gobernaban el reino pero, como afirma Suárez, a un precio muy elevado, porque el acuerdo con la oligarquía nobiliaria les obligaba a pactar con ella las principales decisiones de gobierno ${ }^{49}$. Pronto las divisiones en el seno de la nobleza se hicieron evidentes, inducidas por el condestable que trataba por todos los medios a su alcance de fomentar las disidencias entre ellos. Por de pronto, tanto el doctor Pero Yáñez como el contador mayor Pérez de Vivero, retornaron a sus puestos en el Consejo Real ${ }^{50}$. El príncipe y Pacheco, por su parte, procedieron a entrar en tratos secretos con don Álvaro ${ }^{51}$. Por entonces, enero de 1442, Pacheco había alcanzado el oficio de camarero mayor del príncipe, el más alto puesto en la casa del heredero después del de mayordomo mayor, que todavía seguía desempeñando don Álvaro, cargo que le iba a permitir en adelante controlar por completo cualquier iniciativa o decisión del futuro monarca ${ }^{52}$. En esa cédula, don Enrique le manifestaba que "haçe algún tiempo, antes de que en la villa de Bonilla de la Sierra fuesen proueidas ciertas personas de ciertos oficios de mi casa, yo avía mandado y prometido a vos Juan Pacheco donaros el oficio de camarero mayor". Unos días más tarde, el 15 de enero, el príncipe le prometía que, en remuneración de sus servicios, le concedería unos 1.000 vasallos, y se los entregaría "el día que por parte de vos Juan Pacheco le fuese requerida esta merçed fasta tres días siguientes, e que dentro de tres días si-

${ }^{48} \mathrm{ADF}$, Crónica del Halconero, cap. CCLXXXIII, p. 356.

${ }^{49}$ Luis SuÁREZ FERNÁNDEZ, Los Trastámaras, pp. 172-174.

${ }^{50}$ Crónica de Juan II, año 1442, cap. VII, pp. 608 - 609.

${ }^{51}$ Ibídem, cap. II, p. 607. El halconero por su parte dice lo siguiente: "començaron a tratar secretamente con D. Alvaro por se juntar con él cotra el rey de Navarra e infante su hermano". De todas maneras, el privado de Juan II desconfiaba de ambos: "e no salió el condestable a ello recelándose de engaño, e asy mesmo considerando que por entonce el Príncipe era mucho moço, e que non fallaría en él tanta firmeza como en el rrey de Nauarra" (cap. CCCXX, p. 434).

${ }^{52} \mathrm{ADF}$, Catálogo Antiguo, Leg. $3, \mathrm{n}^{\circ} 9$ y Leg. $42, \mathrm{n}^{\circ} 1$. 
guientes después de ser requerido por vos os entregaré los mill vasallos por juro de heredad" 53 .

Y sin embargo, Pacheco no estaba aún satisfecho con las mercedes recibidas, y para decir verdad jamás lo estaría a todo lo largo de su vida hasta el mismo día de su fallecimiento. Por ello, su príncipe, deseoso de complacer las peticiones de su favorito, le concede en ese año la tenencia de los alcázares de su villa de Molina por juro de heredad ${ }^{54}$. Poco después, recibiría el oficio de guarda del rey que le permitiría embolsarse la cantidad de 6.465 maravedíes de ración, según una libranza del 4 de septiembre de ese año ${ }^{55}$. Sin embargo, la mejor operación que Pacheco realizaría en ese año fue la incorporación, por vía de matrimonio, del señorío de Moguer. La coyuntura política del momento, como siempre, le facilitaría ese incremento notable de su patrimonio. Finalmente, en marzo de 1442 desde la villa de Tordesillas, el príncipe Enrique le concedería los lugares del Campillo, Monesterio y las Posas con todos sus términos ${ }^{56}$.

\section{LA OPERACIÓN "MOGUER"}

El 17 de febrero de 1442, Juan Pacheco, tras un complicado proceso, conseguía la nulidad de su matrimonio con doña Angelina de Luna, prima, como ya hemos visto, del condestable ${ }^{57}$. El matrimonio fue declarado nulo por el vicario general de la diócesis de Segovia, entre otras razones porque había sido fingido, se había hecho por temor y por coacción y, al parecer, no había sido consumado ${ }^{58}$. No hubo, por tanto, desposorio alguno y, en consecuencia, Pacheco quedaba libre para poder contraer nuevo matrimonio con otra mujer. De esta manera, el futuro marqués de Villena, al ganar el pleito interpuesto por su antigua esposa, había dado un primer golpe a don Álvaro de Luna, y le había demostrado que se había zafado definitivamente de su tutela y que ahora, bajo la protección del príncipe Enrique, estaba ya en condiciones de medirse con él. Era una forma de decirle que, a partir de ese momento, - 1442 - el condestable tendría que contar necesariamente con él para todo.

El proceso de nulidad matrimonial le vino como anillo al dedo a Pacheco, pues ya en ese año, y quizás antes, había puesto los ojos en una joven llamada María Portocarrero, sobrina carnal de la primera esposa del condestable. Los destinos del privado del príncipe y los del privado del monarca volvían a cruzarse de nuevo. El doncel había elegido a una

\footnotetext{
${ }^{53}$ ADF, Catálogo Antiguo, Leg. 3, no 10.

${ }^{54} \mathrm{ADF}$, Catálogo Antiguo, Leg. 3, $\mathrm{n}^{\mathrm{o}}$ 12. Tanto esta cédula del príncipe como las anteriores están firmadas en Toro.

${ }^{55} \mathrm{ADF}$, Catálogo Antiguo Leg. 3, no 13.

${ }^{56} \mathrm{ADF}$, caja 2 . El príncipe también le había donado un juro de 25.000 maravedíes situado sobre las rentas reales de los sexmos de Altarejos y Arcas en la tierra de Cuenca.

${ }^{57}$ Véase al respecto mi artículo Las mujeres de Juan Pacheco, de próxima aparición.

${ }^{58}$ Todo el proceso se encuentra en el ADF, Catálogo Antiguo, Leg. 42, no 2.
} 
Portocarrero como esposa; don Álvaro había hecho lo mismo muchos años antes, de la que por cierto no tuvo descendencia alguna. Doña María era hija segunda de Pedro Portocarrero, señor de Moguer, y de Beatriz Enríquez, hija del almirante de Castilla, don Alonso Enríquez ${ }^{59}$. Don Pedro había fallecido en 1429, cuando doña María era aún una niña de pocos años. En su testamento, otorgado en ese año, dejaba a su hija mayor, Juana Portocarrero, el mayorazgo antiguo de la Casa formado por la villa de Moguer - ubicada en la actual provincia de Huelva - y la mitad de las alcaicerías de Sevila ${ }^{60}$. A su segunda hija, María, le dejaba Villanueva del Fresno - situada en la actual provincia de Badajoz - y las casas principales de Sevilla, en la collación de San Bartolomé, que constituía el segundo mayorazgo que su padre Martín Fernández Portocarrero había fundado en $1418^{61}$.

Pacheco se desposó con doña María en ese año de 1442, muy poco después de la ruptura con doña Angelina o, quizás ${ }^{\circ}$, estando aún casado con ella. Según el cronista de los Pacheco, Bilbestre de Henao, era "aún muy mozo" cuando casó con la heredera de Villanueva del Fresno ${ }^{62}$. De lo que no hay la menor duda es de que fue en 1442, pues el cronista de Juan II así lo registra: "e desposado con sobrina del almirante, hija de su hermana y de Pedro Portocarrero, Señor de Moguer" ${ }^{63}$. Y desde luego no lo hizo por imitar al condestable, como afirma Suárez Fernández, sino por la posibilidad de hacerse con un buen patrimonio, como veremos a continuación. En cualquier caso, el matrimonio no fue considerado válido a efectos canónicos hasta muchos años más tarde, en concreto hasta mayo de 1456, año en que el papa Calixto III les concedió autorización para casarse por la iglesia, porque cuando lo hicieron no habían conseguido todavía autorización del ordinario al estar casado Pacheco con la prima del condestable ${ }^{64}$. Al año siguiente, el $7 \mathrm{de}$ marzo de 1457, el marido tuvo que desembolsar a la Cámara Apostólica 600 florines como pago por la dispensa de consanguinidad y por la validez eclesiástica de su segundo matrimonio ${ }^{65}$. Meses más tarde, el ya marqués de Villena conseguía la legitimación de los hijos que le había dado María Portocarrero, porque hasta entonces no habían sido considerados como tales ${ }^{66}$.

En 1442, doña María Portocarrero era una doncella de noble cuna pero de escaso caudal, no porque no lo poseyera sino porque había sido despojada de su patrimonio. En efecto, su padre en su última voluntad, al ser p. 44

${ }^{59}$ Antonio GonzÁlez GómEZ, Moguer en la Baja Edad Media (1248-1538), Huelva, 1977,

${ }^{60}$ Una copia del testamento en ADF, Caja 5, n ${ }^{0} 17$.

${ }^{61}$ Ibídem y GONZÁLEZ GÓMEZ, op. cit., p. 44.

${ }^{62}$ Antonio BILBESTRE DE HENAO, Breve compendio de la Alta y Esclarecida Casa de Pachecos, año 1597, manuscrito existente en la Biblioteca de la Casa Ducal de Frías, fol. 135. Existe una copia de este libro en la Biblioteca Nacional de Madrid, manuscrito $\mathrm{n}^{\circ} 10.565$, copia del siglo XVIII.

${ }^{63}$ Crónica de Juan II, año 1442, cap. II, p. 607.

${ }^{64} \mathrm{ADF}$, Catálogo Antiguo, Leg. 47, Leg. 1.

${ }^{65}$ Ibídem.

${ }^{66}$ Ibídem. 
sus hijas menores de edad, les nombró como tutores y gobernadores de sus posesiones a su pariente micer Egidio Bocanegra, señor de Palma del Río, y al conde de Haro, Pedro Fernández de Velasco ${ }^{67}$. Micer Egidio murió poco después, circunstancia ésta que aprovechó su esposa, Francisca Portocarrero, tía de las niñas, para tomar posesión de Moguer en su propio nombre ${ }^{68}$. Para desgracia de ambas hermanas, el único valedor que podía quedarles, Pedro Fernández de Velasco, fue relevado de la tutoría por Juan II a favor de los alcaldes de Sevilla ${ }^{69}$. En consecuencia, Juana y María Portocarrero fueron despojadas de su patrimonio por su propia tía Francisca que, según González Gómez, gobernó en nombre propio el señorío de Moguer desde 1430 hasta el año $1436^{70}$. En realidad, Francisca sólo se había apoderado de Moguer, pues el concejo de Villanueva del Fresno se negó a obedecerla, y sólo reconoció como señora legítima y efectiva a doña María Portocarrero. Juana, por su parte, la mayor de las hermanas y heredera del señorío de Moguer, que era muda, ingresó en 1442 en el convento de Santa Clara de Palencia, renunciando a Moguer y a la mitad de las alcaicerías de Sevilla a favor de su hermana, a cambio de que ésta le diese una renta de un juro de 20.000 maravedíes anuales $^{71}$. Juan II confirmó la renuncia por una cédula dada en 1443 y, en consecuencia, María se convertía en señora de Moguer, villa que desde el año 1436 había pasado a la jurisdicción de Luis Bocanegra, señor de Palma del Río, por herencia de su madre, Francisca Portocarrero ${ }^{72}$. Don Luis falleció en 1442 no sin antes intentar contraer matrimonio con su prima María, con objeto de legitimar la usurpación de Moguer y apoderarse también de Villanueva del Fresno ${ }^{73}$. Le sucedió su hermano, Martín Fernández Portocarrero, que quedó bajo la tutela conjunta del conde de Haro y de don Juan de Guzmán, conde de Niebla ${ }^{74}$.

Como puede fácilmente pensarse, don Juan Pacheco, desde el momento mismo en que se había casado con María Portocarrero, aprovechando el favor y la privanza que había alcanzado junto al príncipe de Asturias, trataría por todos los medios a su alcance de recuperar Moguer para su esposa. Como en todo lo que se proponía, no descansaría hasta lograrlo. En primer lugar se dio cuenta de que necesitaba el apoyo de don Álvaro de Luna, algo que no le fue difícil conseguir, porque el condestable le necesitaba para tener al príncipe Enrique de su parte en la pugna que mantenía con los infantes de Aragón. Ambos personajes firmaron una alianza de mutuo apoyo contra sus respectivos enemigos - que más adelante analizaremos- en enero de

\footnotetext{
${ }^{67}$ GONZÁLEZ GóMEZ, op. cit., p. 44.

${ }^{68}$ Ibídem.

${ }^{69}$ Ibídem.

${ }^{70}$ Ibídem.

${ }^{71} \mathrm{ADF}$, Documentos del marquesado de Villanueva del Fresno, cajón 70, sin catalogar.

${ }^{72}$ GONZÁLEZ GÓMEZ, op. cit., pp. 44-45.

${ }^{73}$ Ibídem, p. 45.

${ }^{74}$ Ibídem.
} 
1444, un año antes de la derrota definitiva de los infantes ${ }^{75}$ Pacheco conseguía a través de ese pacto que don Álvaro le prometiese pleno apoyo para la recuperación de Moguer. Unos meses después, en marzo de ese año, el condestable lograba que Juan II concediese a Pacheco la villa de Villena o en su lugar, si así lo prefería, 700 vasallos en los lugares que eligiese de la tierra de Sevilla o Córdoba, además de darle toda clase de seguridades de que trataría por todos los medios, recurriendo incluso a la fuerza, de que Moguer le fuese devuelta a su mujer ${ }^{76}$. Poco después, el rey desde Tordesillas ordenaba a don Juan de Guzmán, conde de Niebla, que se encargase de restituir la villa de Moguer a María Portocarrero y a su esposo, Juan Pacheco, ya que le había sido ocupada por su tío micer Gilio Bocanegra, y ahora la tenía su hijo Martín Fernández Portocarrero ${ }^{77}$. Comisión similar recibió también don Gutiérre de Sotomayor, maestre de la orden de Alcántara y, poco después, el propio príncipe de Asturias ${ }^{78}$ Don Enrique, desde Ávila, el 20 de mayo de ese mismo año, ordenaba a Lope de Orsales que marchase a Moguer y trabajase cuanto pudiese para dar posesión de la villa a Juan Pacheco.

A pesar de los mandatos reales no iba a ser nada fácil la devolución de Moguer a María Portocarrero. El usurpador, Martín Fernández Portocarrero, exigía una compensación económica por el abandono de esa villa. El príncipe Enrique, acosado por Pacheco, se vió obligado a enviar desde Ávila, en mayo de 1444, una cédula dirigida a los tres aristócratas más poderosos del reino de Sevilla, los condes de Niebla y Arcos y el Adelantado Mayor de Andalucía, Per Afán de Ribera, para que por todos los medios posibles tratasen de convencer a Portocarrero de que debía entregar Moguer a su legítima señora ${ }^{79}$. Poco después sería Juan II, a instancias de don Alvaro de Luna y del propio príncipe, quien se dirigiese a don Martín para que devolviese la villa a Pacheco, a fin de evitar un posible enfrentamiento armado, asegurándole, a cambio, una equivalencia por la pérdida de sus derechos a Moguer ${ }^{80}$. En concreto, el monarca prometía entregarle cuatro villas, Hornachuelos, Peñaflor, Posadas del Rey y Santaella, que se separarían de la jurisdicción de Cordoba y se le concederían en señorío. Por su parte, Juan Pacheco, recibiría otra cédula real, despachada también como la anterior desde Roa, el 16 de agosto de ese mismo año, en la que le hacía merced de la villa de Moguer $^{81}$. En realidad, el rey se la concedía a doña María Portocarrero, como única y legítima heredera de Pedro Portocarrero, pero lo hacía

${ }^{75} \mathrm{ADF}$, Catálogo Antiguo, Leg. 56, no 6.

${ }^{76} \mathrm{ADF}$, Catálogo Antiguo, Leg. 56, no 4.

${ }^{77} \mathrm{ADF}$, Catálogo Antiguo, Leg. 56, $\mathrm{n}^{\circ} 14$ y Documentos del marquesado de Villanueva del Fresno, cajón, sin catalogar.

${ }^{78} \mathrm{ADF}$, Catálogo Antiguo, Leg. 56, no 14 y GonZÁLEZ GóMEZ, op. cit., p. 46.

${ }^{79} \mathrm{ADF}$, Catálogo Antiguo, Leg. 56, no 14.

${ }^{80} \mathrm{ADF}$, Caja 2, no 19 y GoNZÁlEZ GóMEZ, op. cit., p. 47.

${ }^{81}$ Ibídem. 
para euitar ynconuenientes, ruydos y peleas, y por contenplaçión de Juan Pacheco, su marido, y por respeto a los buenos y leales seruiçios que él a mí me ha fecho, espeçialmente por aver trabajado mucho por averme librado de la opresión del rey de Navarra, de que yo soy libre loado nuestro sennor.

No me cabe la menor duda de que la operación de Moguer se encuentra íntimamente relacionada con el enfrentamiento entre Juan II y Álvaro de Luna, de una parte, y los infantes de Aragón de la otra. Tanto don Álvaro como el monarca no tuvieron otra alternativa que plegarse a los deseos del hombre que dominaba al príncipe, a fin de evitar la neutralidad de este último en ese conflicto o, lo que era aún peor, su inclinación y apoyo al partido aragonés. Sólo así puede explicarse el hecho, a todas luces insólito, de que toda una corte, desde el rey hasta el último servidor, se movilizase de la manera que estamos describiendo, sólo para satisfacer los deseos del privado del heredero. Todos ellos en función de los intereses de Pacheco; hasta este extremo llegaban las intrigas políticas y la bajeza de los personajes que las protagonizaban. Es más, estoy absolutamente seguro de que todas las donaciones que Pacheco recibió entre los años de 1442 y 1446, bien fuesen del príncipe o del propio rey, se explican como consecuencia de la delicada coyuntura política por la que atravesaba la monarquía castellana desde que en julio de 1443, como veremos, Juan de Navarra perpetrase el que Suárez Fernández define como golpe de estado de Rámaga, para apoderarse de la persona de Juan II y alejar de la corte a todos los partidarios de Álvaro de Luna $^{82}$. Pacheco, a este respecto, supo jugar habilmente sus cartas. Se sabía que desde hacía ya algunos años dominaba casi por completo la voluntad del heredero del trono, por esta razón todo aquel bando que aspirase a controlar el poder intentaba conseguir su apoyo o, al menos, su neutralidad, en especial desde que en marzo de 1444 el rey, finalmente, se decidió a conceder a su hijo el principado de Asturias, una rica plataforma económica -como sugiere Luis Suárez - desde la que poder actuar y, en consecuencia, dar su apoyo al partido que más señoríos le ofreciese ${ }^{83}$. El monarca y don Álvaro trataron de ganarlo para su causa. El precio del acuerdo, por desgracia, ya lo conocían demasiado bien. Por ello no puede resultar extraño la abrumadora cascada de donaciones de villas y de rentas que Pacheco logra incorporar a su aún modesto patrimonio entre 1443 y los años inmediatamente posteriores a la batalla de Olmedo. En verdad, la operación de Moguer no fue más que una de ellas y, me atrevería a decir, ni siquiera la más importante, teniendo en cuenta la calidad de las villas que por entonces consiguió: Utiel, Jumilla y, sobre todo, el marquesado de Villena.

Moguer, por otra parte, para el privado del príncipe, bien es verdad, tenía una significación especial: formaba parte del patrimonio de su mujer que le había sido arrebatado por un familiar cercano pero, a fin de cuentas, un

\footnotetext{
${ }^{82}$ SUÁREZ FERNÁNDEZ, Nobleza y Monarquía, pp. 114-115.

${ }^{83}$ Ibídem, pp. 116-117.
} 
usurpador. Había que recuperarla al precio que fuese, involucrando a la monarquía si resultaba necesario, porque se trataba para sus ambiciosos planes nada más ni nada menos que de la dote que le aportaría su esposa, y él un caballero en continuo e imparable ascenso social, la persona que, como camarero mayor, dirigía la Casa del príncipe heredero no podía permitir que un modesto señor de Palma del Río se la arrebatase. Por aquellos años iniciales de su privanza, Pacheco solía culminar con éxito las operaciones que minuciosamente diseñaba para hacerse con un rico patrimonio que le permitiese convertirse en gran señor de Castilla. Poco a poco, paso a paso, pactando con quien fuese, aprovechando con extrema habilidad una coyuntura compleja y difícil, pasó a convertirse en cuestión de cinco años, no ya sólo en uno de los aristócratas más ricos del reino, sino también en uno de los más sólidos poderes con los que a partir de 1443 y hasta su muerte, en 1474, había necesariamente que contar para cualquier operación política que se fraguase en Castilla.

Pacheco utilizaría pues, y a fondo, toda la fuerza y el poder de la monarquía para conseguir finalmente apoderarse de Moguer. Así, logró que Juan II, en la misma cédula que había dirigido a Martín Fernández Portocarrero ordenándole que en un plazo no superior a los cuatro días, después de recibir el mandato regio, entregase Moguer a doña María, le propusiese también a modo de celada, que aceptase recibir una compensación por su renuncia. Todo ello lo hacía el monarca para que cediese a los deseos del privado de su hijo, porque, en su opinión, éste último había colaborado muy decisivamente a librarle de la pesada tutela que su primo el rey de Navarra le había impuesto en Rámaga un año antes. Ofrecía a don Martín cuatro villas que pertenecían a la jurisdicción de Córdoba, pero si en conjunto las cuatro no alcanzaban la cifra de población que tenía Moguer - que se calculó en 600 vecinos-, ni el valor de su fortaleza - 400.000 maravedíes- se le compensaría de tal forma que los vasallos que faltasen se podrían fijar en otros lugares cercanos a esas mismas villas que se le prometían. Y por lo que se refería a las rentas, Juan II le entregaría también las alcabalas y tercias de esas cuatro villas, para que de esa manera alcanzasen el valor de la villa de Moguer. Su intención, por consiguiente, sería concederle esas cuatro villas que serían enajenadas del alfoz de Córdoba, y quedarían en poder de una persona de la confianza regia, hasta que otras dos personas se encargasen de hacer el recuento total de vasallos que habitaban en Moguer y en las cuatro villas cordobesas. Si se averiguaba que había igualdad entre ellas, entonces las escrituras que poseía Martín Fernández Portocarrero pasarían a poder de su tío, el conde de Haro, que las retendría también, en cualquier caso, si se producía una desigualdad de vasallos a favor de Moguer. En este último caso, el rey se comprometía a satisfacerle esa demasía sobre el número de vasallos que hubiese en esas villas cordobesas y en lugares cercanos a ellas. Finalmente, el monarca le hacía saber que, si al final del recuento había más vasallos en esas villas cordobesas que en Moguer, don Martín recibiría sólo dos de ellas "si ellas dos bastaren para la equiualençia". Don Martín, además, podría 
tener la seguridad de que si doña María fallecía sin dejar hijos legítimos, el mayorazgo de los Portocarrero volvería a su poder.

El acuerdo era ciertamente ventajoso para el señor de Palma del Río, porque de esa manera podía hacerse con cuatro villas que se hallaban casi a las mismas puertas de Córdoba, con lo que esa cercanía podía significar a la hora de obtener más poder en el cabildo municipal que regía los destinos de esa ciudad, además de que con su incorporación ampliaba sustancialmente el señorío familiar de Palma. En un principio, don Martín se mostó reacio a entregar Moguer, entre otras razones porque sabía perfectamente que la ciudad de Córdoba iba a impedir por todos los medios a su alcance ese grave despojo de su jurisdicción, como así sucedería. Pero al final, tras la victoria del bando real en Olmedo, que se tradujo en la concesión del marquesado de Villena a su rival, Pacheco, no tuvo más remedio que ceder. Don Martín abandonó, muy a su pesar, la villa de Moguer, como así lo haría constar años más tarde, en 1456, cuando declaró que lo había hecho porque "no fallaría quien mi justiçia me guardase ni con la dicha María, su muger [de Juan Pacheco], nin yo la osaría con él [Pacheco] proseguir, por tener, como tiene, tan gran parte en el rey [Enrique IV], nuestro señor, e en su reyno e en los señores de su consejo" ${ }^{84}$. Enfrentarse con el flamante marqués de Villena era exponerse a una derrota segura. Don Martín, por supuesto, era consciente de ello, de ahí su amarga declaración a este respecto; no podía luchar para defender sus "derechos e justos títulos" contra una persona tan afecta al nuevo monarca porque "se trabajó con todas sus fuerzas por me quitar e desapoderar de fecho, y contra todo derecho me desapoderó... de la villa de Moguer" ${ }^{85}$.

Al final, don Martín se vió obligado a ceder Moguer a Pacheco. Tampoco logró que la ciudad de Córdoba le cediese esos cuatro pueblos mencionados, a pesar de que el monarca intentó hacer efectiva esa recompensa. La fuerte oposición del concejo cordobés a ese mandato real impidió que la ciudad perdiese esos pueblos de tanto valor estratégico para el mantenimiento de su alfoz ${ }^{86}$. De esta manera, don Martín, que llegó incluso a ocupar, aunque por poco tiempo, la villa de Hornachuelos, vió frustrado sus planes de expansión señorial por el territorio cordobés, y para su mayor amargura la compensación prometida por la pérdida de Moguer tardó en llegar. En efecto, en la cédula de 1444, el rey, consciente de que Córdoba no toleraría la enajenación de esas cuatro villas de su territorio, le había prometido a don Martín que, si no se hacía efectiva esa donación, tendría a su disposición, y a la de su tutor, el conde de Haro, la renta de los diezmos de la mar para que pudiesen tomar de ella todo lo que rentase cada año la villa de Moguer, y la siguiesen cobrando al menos hasta el momento en que se le pudiese conceder

\footnotetext{
${ }^{84}$ GONZÁLEZ GóMEZ, op. cit., p. 47.

${ }^{85}$ Ibídem.

${ }^{86} \mathrm{El}$ monarca llegó incluso a separạr esas villas de la jurisdicción de Córdoba, y a concedérselas a don Martín por un privilegio otorgado en Roa el 16 de agosto de 1444.
} 
otra villa en equivalencia por la pérdida ${ }^{87}$. Al fin, en 1457 , desaparecido ya Juan II, el nuevo monarca, Enrique IV, llegó a un acuerdo con don Fernando de Velasco, suegro de don Martín, para tratar de hacer efectiva la recompensa prometida $^{88}$. Se supo entonces, por una pesquisa realizada a tal fin, que Moguer tenía 495 vecinos. El rey prometió darle por ellos la cantidad de 1.750.000 maravedíes. Se acordó también que se le entregarían 170.000 maravedíes de renta anual en equivalencia por las rentas de la villa y otros 11.000 maravedíes anuales por el diezmo del aceite. En total, por las rentas de Moguer se le darían 181.000 maravedíes de renta anual que, a razón de 20.000 maravedíes el millar, montarían una suma que oscilaría entre 300.000 y 620.000 maravedíes anuales. La fortaleza de la villa fue valorada en 100.000 maravedíes. Se le compensaría también por la pérdida de las rentas de Moguer, desde el 5 de diciembre de 1444 hasta que se vió obligado a cederla, a fines de 1445. En definitiva, don Martín recibió por Moguer la bonita suma de 7.442.736 maravedíes, cantidad ésta que, procedente de las rentas de los diezmos de la mar, le fue entregada por su tutor, el conde de Haro $^{89}$.

Así pues, en 1445, don Martín Fernández Portocarrero perdía la villa de Moguer, aunque sería generosamente recompensado por Juan II y Enrique IV. El poder real se hacía cargo de todos los gastos que había generado la recuperación de esa villa para Pacheco y su esposa. Estos últimos recibieron Moguer por donación real, tras un largo proceso, sin haber desembolsado ni un solo maravedí ${ }^{90}$. Unos años antes, en 1444, María Portocarrero conseguía que Juan II le concediese una nueva merced: un juro de 10.000 maravedíes situado en las rentas del almojarifazgo de Sevilla, en virtud de la renuncia que a favor de ella habían hecho los herederos de Luis Fernández Marmolejo, veinticuatro de Sevilla y antiguo tutor de doña María y de su hermana ${ }^{91}$.

\section{Del Golpe de RÁmaga a Olmedo. LA INCORPORACIÓN DEL MARQUESADO DE VILLENA}

El proceso de incorporación del señorío de los Portocarrero a los dominios de Juan Pacheco sólo pudo ser posible por la compleja coyuntura política que estaba atravesando el reino de Castilla tras el golpe de estado que había dado Juan de Navarra en julio de 1443. En efecto, el 9 de julio de ese

\footnotetext{
${ }^{87}$ Sobre el significado de la renta de los diezmos de la mar para la Corona de Castilla ver mi trabajo "Los condestables de Castilla y la renta de los diezmos de la mar" en La Fortuna y el Poder, Universidad de Cádiz, 1996, p. 465-497.

${ }^{88} \mathrm{El}$ acuerdo se firmó en Palma del Rio el nueve de junio de ese año. ADF, Documentos del marquesado de Villanueva del Fresno, Cajón 70, sin catalogar.

${ }^{89}$ GonZÁlez GómEZ, op. cit., p. 48.

${ }^{90}$ La donación real de Moguer a Pacheco y a su esposa fue en el año 1444. Juan II se la confirmaría en 1450 y Enrique IV a su vez en 1456. GóNZÂLEZ GóMEZ, op. cit., p. 48.

${ }^{91}$ Esta donación le fue confirmada a doña María por un privilegio real dado en Arévalo el 3 de agosto de 1447. ADF, Documentos del marquesado de Villanueva del Fresno, cajón 70, sin catalogar.
} 
año don Juan consiguió que el Consejo Real, en una decisión sin precedentes, ordenara la detención del contador Vivero y del doctor Pero Yáñez ${ }^{92}$. Fue un verdadero golpe de mano, dado en Rámaga, una aldea al sur de Madrigal, que, para Suárez Fernández, "contribuyó a encender la hoguera de la guerra civil y tuvo como lejana e inesperada consecuencia la eliminación definitiva de los infantes de Aragón"93. El objetivo del golpe, para el citado historiador, "era de una audacia singular: reducir al rey a prisión y convertir a la monarquía en tutela" ${ }^{94}$. La acción de Rámaga, sin embargo, tenía un punto débil: se le había informado al príncipe, que dio su asentimiento a la prisión de los hombres del condestable, pero, inmediatamente después, comenzó a arrepentirse y a dar marcha atrás, tras la oportuna intervención al respecto de don Lope Barrientos ${ }^{95}$. El obispo, en efecto, le convenció de que había sido engañado por Juan de Navarra, y que, al dar su consentimiento, había colaborado a convertir en prisionero a su propio padre ${ }^{96}$. Don Enrique intentó justificarse ante su preceptor, afirmando que lo había hecho "por quanto personas dinas de fee le avian dicho que lo querian prender a él e a Juan Pacheco su criado" "97. Barrientos logró, no sin dificultades, que el príncipe se entrevistara con su padre. Pero había que convencer además al privado. Pacheco, por esos días, se hallaba enfermo "de gran dolencia", según manifiesta el halconero ${ }^{98}$. El príncipe y el obispo le visitaron, "e desque el dicho obispo falló al dicho Juan Pacheco, e le preguntó de la disposición de su salud, e le fue rrespondido", le hizo responsable por complicidad de la acción de Rámaga ${ }^{99}$. Pacheco, como siempre, trató de excusarse y adujo ignorancia $^{100}$ :

Nunca Dios le lleuantase de aquella cama si tal cosa avía sabido, ni tal trato avía cabido, mas que como él estava tan travajoso de aquella dolençia, que non podiera yr con el señor Príncipe a fazer rruerençia al señor Rey.

El privado del príncipe trataba, como era habitual en él, de zafarse de aquellas acusaciones y decidió responsabilizar directamente al rey de Navarra

\footnotetext{
${ }^{92}$ SUÁREZ FERNÁNDEZ, Los Trastámaras, pp. 176 y ss.; Nobleza y Monarquía, pp. 114-115 y Enrique IV, p. 45 y ss. Véase también Crónica del Halconero, cap. CCCXXI, pp. 435 y ss. Las repercusiones que para la región andaluza tuvo este golpe las ha estudiado de una forma espléndida Emilio CABRERA MUNOZ, en su trabajo Andalucía y los infantes de Aragón, "Acta Historica et Archaeologica Mediaevalia", 22 (= Homenatge al Dr. Manuel Riu $i$ Riu, vol. 2) (Barcelona, 2001), pp. 699-720.

${ }^{93}$ Ibídem.

${ }^{94}$ Ibídem.

${ }^{95}$ Crónica del Halconero, cap. CCCXXI, p. 439 y Crónica de Juan II, año 1444, capítulos I al X, pp. 614-619.

${ }^{96}$ Ibídem.

${ }^{97}$ Ibídem.

${ }^{98}$ Ibídem.

${ }^{99}$ Ibídem.

${ }^{100}$ Ibídem.
} 
y a sus partidarios de que "le fezieron topar en aquella errada" ${ }^{101}$. Le aseguró, entonces, al obispo, que trataría de remediarlo. Barrientos, por su parte, le respondió que la mejor forma de hacerlo sería retirarse de la corte y marchar a Segovia, que era un lugar seguro porque pertenecía a los dominios del príncipe $^{102}$. Desde allí podían ambos enmendar su acción y denunciar la prisión del monarca. A Pacheco le pareció bien la sugerencia del clérigo, "non envargante que él estaua tan flaco"103. Poco después, utilizando el pretexto de una partida de caza - "correr monte"-, el príncipe, Pacheco y Barrientos huyeron a Segovia. La huida de don Enrique encolerizó a Juan de Navarra que sospechaba que había sido el obispo quien trataba de sustraer al príncipe de su influencia, "rreçelando que le desviaría de su opinión"104. Desde Segovia, el príncipe, asesorado por Pacheco y el obispo, decidió entonces entrar en tratos con el condestable, y a tal fin envió una embajada a don Álvaro presidida por Barrientos “para traer a sí los más que podiese de los grandes del rreyno, así perlados como cavalleros" ${ }^{105}$. El condestable, no obstante, seguía desconfiando de don Enrique y de Pacheco, "por ser tan moço el señor Príncipe y no sería constante para lo llevar al cabo hasta la devida execuçión", y porque, sobre todo, pensaba que la unión de sus fuerzas con las del heredero no eran suficientes para derribar a los infantes ${ }^{106}$. Barrientos, no obstante, intentó convencerle de lo contrario.

La situación, sin embargo, seguía siendo bastante confusa, entre otras cosas porque Juan de Navarra, conociendo las intenciones de Barrientos, trató de nuevo de atraerse al príncipe, con la expresa intención de acabar de una vez con don Álvaro ${ }^{107}$. D. Enrique, por su parte, aparentemente se dejaba querer, pero en realidad, aconsejado por el obispo, trataba de reconciliarse con su padre. A tal fin se desplazó a la corte, que por entonces se encontraba en Tordesillas, con la oculta intención de hablar secretamente con su padre, aunque en apariencia la marcha la hacía para unirse a Juan de Navarra ${ }^{108}$. Poco después de llegar el príncipe, se celebraron las bodas ya pactadas de Juan de Navarra con una hija del almirante y la de su hermano Enrique con otra del conde de Benavente ${ }^{109}$. Mientras tanto, el rey había sabido por Barrientos que el príncipe, a pesar de que había jurado poco antes, en Arévalo, que ayudaría a su suegro a destruir al condestable, se hallaba en

${ }^{101}$ Ibídem.

${ }^{102}$ Ibídem.

${ }^{103}$ Ibídem.

${ }^{104}$ Ibídem, p. 440. Pacheco recorrió el camino hasta Valladolid "en andas".

${ }^{105}$ Ibídem, p. 441.

${ }^{106}$ Ibídem.

${ }^{107}$ Ibídem, cap. CCCXXVI, p. 447. Sobre la política desarrollada en estos años por los infantes de Aragón sigue siendo de enorme interés el libro de Jaime VICENS VIVES, Juan II de Aragón. Monarquía y Revolución en la España del siglo XV, Barcelona, 1955.

${ }^{108}$ Ibídem, p. 448.

${ }^{109}$ Ibídem . 
tratos secretos con éste último para liberarle ${ }^{110}$. El propio don Enrique así se lo manifestó personalmente a su padre, tras entrevistarse con él en Tordesillas. Así las cosas, el príncipe regresó a Segovia decidido ya a dar su apoyo a don Álvaro de Luna ${ }^{111}$. Se entra en tratos con el conde de Alba y con el arzobispo de Toledo a fin de sumar fuerzas contra los infantes ${ }^{112}$. Juan de Navarra, en un último intento de congraciarse con su yerno, que pronto dejaría de serlo, envió a Alvar García de Santa María para convencerlo de que volviera a su opinión, pero ya era tarde. Pronto el príncipe se atrajo a importantes personajes de la alta nobleza como los condes de Haro, Plasencia, Alba y Castañeda, el arzobispo de Toledo e Íñigo López de Mendoza, decididos ahora a enfrentarse con la tiranía del rey de Navarra ${ }^{113}$. Don Enrique marchó primero a Ávila y de esta ciudad a Burgos, acompañado por Pacheco, Barrientos y los nobles citados, que había logrado reunir una hueste formada por 3.000 jinetes y 4.000 peones $^{114}$. El enfrentamiento parecía inminente, más aún cuando Juan II había logrado huir de Portillo, en donde se hallaba recluido por orden de Juan de Navarra, y refugiarse en Dueñas, para juntarse allí con su hijo y el condestable ${ }^{115}$. El combate definitivo se produciría, como veremos, en Olmedo. Los infantes de Aragón fueron completamente derrotados.

Si me he detenido hasta ahora, quizá más de lo prudente, en describir los hechos que condujeron a la batalla de Olmedo y a la derrota de los infantes, ha sido sencillamente porque tuvieron honda repercusión en la vida de Pacheco y, sobre todo, en la formación de su patrimonio. En efecto, desde que se produjo el golpe de Rámaga, Juan Pacheco comprendió inmediatamente que podría sacar importantes ventajas de la grave situación en que se hallaba el monarca. En principio, como ya hemos señalado, la denuncia de Rámaga, a instancias del obispo Barrientos, y el consiguiente intento de aproximarse a don Álvaro le trajo inmediatas ventajas. Si Juan de Navarra pretendía atraerle a su bando prometiéndole donaciones, don Álvaro de Luna sería incluso más efectivo a la hora de concedérselas. Ya hemos visto cómo consigue recuperar Moguer y la herencia de su esposa. Pronto entrará en posesión de otras villas, pero antes será su protector quien recibirá diversos bienes por la colaboración con su padre. En primer lugar, Juan II le haría señor de Écija y poco después recibiría la villa de Lorca "por vos heredar y porque tengades con que mejor podays sostener vuestro estado e casa" 116 . De todas formas, la gran prebenda le llegaría a comienzos de marzo de 1444 cuando Juan II, por un albalá

${ }^{110}$ Ibídem, cap. CCCXXVIII, pp. 450-451.

${ }^{111}$ Ibídem, p. 451.

${ }^{112}$ Crónica de Juan II, cap.XI, pp. 619-620.

${ }^{113}$ Ibídem, cap. XV, p. 622.

${ }^{114}$ Ibídem.

${ }^{115}$ Ibídem, cap. XVI, p. 623.

${ }^{116}$ La concesión de Écija en Manuel GonZÁLEZ JIMÉNEZ, Los señorios andaluces del príncipe de Asturias en Orígenes del Principado de Asturias, Oviedo, 1998, pp. 183-207 y en Luis SUÁREZ FERNÁNDEZ, Enique IV p. p. 52 . La donación de Lorca en ADF, Catálogo Antiguo, Leg. 56. El privilegio de concesión va firmado por el rey en Tordesillas el 4 de octubre de 1443. 
firmado el día tres de ese mes, se compromete a entregarle el principado de Asturias $^{117}$. Desde ahora don Enrique consigue definitivamente una base económica lo suficientemente fuerte, como para constituir por sí solo un gran poder en el reino castellano. A ello había que añadir las villas del marquesado de Villena, que había recibido en dote de su padre cuando contrajo matrimonio con Blanca de Navarra de las que ahora entra en plena posesión ${ }^{118}$. El enriquecimiento del príncipe contribuiría decisivamente al incremento patrimonial de su valido, pero antes hubo que pactar con don Álvaro de Luna. En efecto, en enero de 1444, en Talavera, Pacheco y el condestable firmaron una alianza de mutuo apoyo contra sus respectivos enemigos ${ }^{119}$. El primero conseguía, como ya hemos visto en páginas anteriores que Álvaro le prometiese pleno apoyo para la recuperación de Moguer, pero al mismo tiempo lograba también una pieza largamente acariciada: el condestable le hacía saber que haría todo lo posible para que el rey le hiciese entrega de la villa de Villena, pero si ello no era posible se le darían, a cambio, 700 vasallos en tierras de Sevilla o de Córdoba, en cualquiera de esas dos ciudades que más le interesase. Si quería recuperar el poder en Castilla, a don Álvaro no le quedaba más remedio que plegarse a las condiciones que le impusiese su antiguo protegido. De aquí la firma de esa confederación; el condestable le necesitaba para tener al príncipe Enrique de su parte en la larga pugna que mantenía con los infantes de Aragón, y más aún en aquellos momentos tan cruciales, en los que fácilmente podría adivinarse que más pronto que tarde se produciría un choque frontal que decidiría de una vez el destino definitivo del reino. En aquella coyuntura, don Álvaro le prometía todo con tal de ganar su concurso. Y lo que era mucho más importante, cumpliría sus promesas tras la batalla de Olmedo. Las dos se hicieron efectivas bien pronto. El caso de Moguer ya lo hemos analizado. La segunda, Villena, caería poco después. En efecto, en el mismo día en que Pacheco pacta con don Álvaro recibe un albalá real firmado en Tordesillas por Juan II, en el que le prometía que "le amaría mucho y se fiaría de su persona, haçiéndole muchas merçedes, acrecentando su estado y honor, guardando y defendiendo su persona y casa de todo mal y daño, y que nunca soliçitaría ni permitiría apartarle de la privança y lugar que tenía con el dicho sennor prínçipe Enrique, su hijo, y en remuneraçión de sus muchos seruiçios le hacía merçed de la villa de Villena, con su fortaleza, jurisdiçión e rentas" ${ }^{120}$. El monarca le aseguraba también que pondría en su poder esa villa en un plazo no superior a los sesenta días después de la concesión de esa merced, y para hacerla efectiva ordenaría al doctor Pero

\footnotetext{
${ }^{117}$ SUÁREZ FERNÁNDEZ, Enrique $I V$, p. 47.

${ }^{118} \mathrm{ADF}$, Catálogo Antiguo, Leg. 56, n ${ }^{\circ}$ 10. La concesión del marquesado al príncipe se hizo por cédula dada en Roa el 6 de abril de 1444 . Unos meses más tarde, don Enrique, desde Toledo, ordenó al padre de Juan Pacheco, Alonso Téllez Girón, que tomase posesión en su nombre de la villa de Chinchilla y de otros lugares del marquesado.

${ }^{119} \mathrm{ADF}$, Catálogo Antiguo, Leg. 56, $\mathrm{n}^{0} 6$.

${ }^{120} \mathrm{ADF}$, Catálogo Antiguo, Leg. 5. Ver a este respecto mi trabajo Las primeras ordenanzas municipales de Villena (1440-1445) en Estudios sobre ordenanzas municipales (siglos XIV-XVI), Universidad de Cádiz, 1998, pp. 48-49.
} 
Yáñez, que en ese momento detentaba la jurisdicción sobre Villena, que durante ese período entregase la villa a Pacheco. En cualquier caso, si la donación de Villena no se llevaba a efecto, el rey se comprometía a donarle 700 vasallos en los lugares que él personalmente eligiese de la tierra de Sevilla o de Córdoba. Así mismo, le garantizaba la posesión de Moguer, le prometía defenderle en todo su estado, y le aseguraba que no padecería mal ni daño mientras el príncipe continuase sujeto a la obediencia paterna. Finalmente, el 17 de agosto de 1444, el príncipe de Asturias, con el beneplácito de Juan II y la aquiescencia de Álvaro de Luna, le nombra su mayordomo mayor ${ }^{121}$. El nombramiento se hacía por los consejos que había dado a don Enrique "para que yo me disposiese a trabajar como trabagé por la deliberación del dicho rey, mi sennor, e guarda de su persona e preheminençia real, y los muchos trabajos e peligros que ende rescebistes". El condestable, presionado por el príncipe y por el propio rey, no tuvo más remedio que renunciar a ese oficio que había desempeñado regularmente desde el año 1435. Pero desde luego no lo hacía gratis. A pesar de la necesidad que tenía del apoyo del heredero y de su privado para acabar con los infantes de Aragón, don Álvaro exigió y obtuvo 100.000 maravedíes por su renuncia. Con este nombramiento, el heredero del trono castellano dejaba en manos de su privado, como jefe de su Casa, la defensa de sus intereses personales, y más aún el control de todos los asuntos relacionados con la política del reino que pudiesen afectarle.

Pocos meses después, en septiembre de ese mismo año, el futuro Enrique IV se confederaba con su padre Juan II y con una serie de grandes nobles, entre ellos Pacheco, para luchar contra los infantes de Aragón y, en especial, contra el rey de Navarra ${ }^{122}$. Por su participación en esta alianza Pacheco supo sacar de nuevo beneficios. En efecto, el 2 de septiembre de 1444, Juan II le concedía los lugares de Salvatierra, Salvaleón y Villanueva de Barcarrota, aldeas de Badajoz, a las que eximió de la jurisdicción de esa ciudad y las convirtió en villas ${ }^{123}$. La justificación de la donación es la de siempre: por haber libertado al monarca de la prisión en que le tenía el rey de Navarra.

Al comenzar el año 1445, el nuevo mayordomo del príncipe heredero de Castilla podría sentirse íntimamente satisfecho, pues hasta ese momento las circunstancias le habían sido enormemente favorables en todos los sentidos. Había pasado de ser un simple doncel de Enrique IV, sin apenas futuro, a señor de vasallos y a detentar los máximos cargos palatinos en la Casa del

${ }^{121} \mathrm{ADF}$, Catálogo Antiguo, Leg. $3, \mathrm{n}^{0} 6$.

${ }^{122} \mathrm{ADF}$, Catálogo Antiguo, Leg. 56, $\mathrm{n}^{\mathrm{0}} 6$.

${ }^{123} \mathrm{La}$ separación de Villanueva de Barcarrota de la jurisdicción del concejo de Badajoz tuvo lugar el 13 de agosto de 1444 . Pacheco, sin enbargo no pudo de momento tomar posesión de esas villas extremeñas, como veremos en otra ocasión, hasta mucho más tarde, El Archivo Ducal de Frías no conserva la cédula original del 2 de septiembre, pero sí se ha copiado en el libro Noticia de todos los lugares de que se componen los estados de Villena, Castañeda y Aguilar que figuraba en la biblioteca de la Casa Ducal de Frías cuando ésta se hallaba en el castillo de pueblecito cordobés de Montemayor. Véase a este respecto, el espléndido trabajo de Alfonso DOMÍNGUEZ VINAGRE, El señorío de Salvatierra en la Baja Edad Media, Diputación de Badajoz, 2009, pp. 99 y ss. 
príncipe de Asturias. Señor de Utiel, Lozuza, Munera, etc, miembro del Consejo Real, camarero mayor y mayordomo mayor de don Enrique. Su hermano, Pedro Girón, por su parte, aquel a quien Palencia calificaba de "bien quisto del Príncipe, por quanto más descaradamente que los otros, se entregaba a un desenfreno muy conforme con sus gustos, y tal, que sonroja y apena referir por que clase de méritos y por qué grados fue subiendo a la más alta privanza", había alcanzado también puestos muy revelantes. En efecto, si bien hasta el año 1442 había permanecido al servicio de don Enrique, siempre bajo la sombra política de su hermano mayor, pero sin haber recibido merced alguna, ahora, al compás del ascenso de su hermano, comienza a ser premiado también con diversas prebendas. Las primeras mercedes que Girón recibiría corresponden al año 1443: oficial de cuchillo de la mesa del príncipe, camarero mayor por cesión de su hermano, tenente de los alcázares y puertas de Toledo mientras esta ciudad había estado bajo la gobernación del heredero, y notario mayor de sus reinos por donación de Juan II a petición de su hijo ${ }^{124}$. Es precisamente a partir de ese año, 1443, cuando Girón, según señala con acierto el profesor Ladero Quesada, comienza a manifestar interés por Andalucía, y a penetrar en su territorio va a dirigir su atención. Conseguiría del príncipe Enrique varias donaciones, a la misma par que su hermano y por las mismas causas: la alcaldía mayor de Écija, el alguacilazgo de Baeza, el importe de los portazgos de Úbeda, Jaén, Baeza y Andújar, el almojarifazgo de Jaén y el importe del impuesto sobre el comercio fronterizo ${ }^{125}$. Estas concesiones las recibe en las ciudades y villas andaluzas que formaban parte de la dotación del principado de Asturias, con la secreta esperanza de apoderarse más adelante de alguna de ellas y convertirla, como veremos en su día, en la base de un estado territorial propio en la Andalucía Bética. De hecho, cuando, en octubre de 1444, Juan II le confía al príncipe el gobierno del reino de Jaen, será Pedro Girón quien en la práctica lo desempeñe ${ }^{126}$. De todas maneras, no será Andalucía la única región por la que Girón manifestará interés, pronto la coyuntura política le permitiría penetrar en tierras de la comarca de Valladolid que pertenecían en ese momento al rey de Navarra. Al año siguiente, 1444, don Pedro se hará también con rentas y oficios en la villa de Medina del Campo ${ }^{127}$. Esta última merced fue obra de Juan de Navarra, en un último intento por congraciarse con los dos hermanos, con la esperanza, pronto fallida, de inclinar a su favor la voluntad del heredero del trono en la larga pugna que sostenía con don Álvaro de Luna.

La fortuna de ambos hermanos llegará a su cénit en 1445, año en que se convierten en grandes señores de Castilla tras la derrota de los infantes de Aragón en la batalla de Olmedo. En efecto, aunque se llegó a firmar una tregua, el 4 de noviembre de 1444, por cinco meses - tregua concertada entre

\footnotetext{
${ }^{124}$ Alfonso Franco Silva, Don Pedro Girón, fundador de la Casa de Osuna (1423-1466), recogido en el libro Señores y señoríos, Universidad de Jaén, 1997, p. 228.

${ }^{125}$ Ibídem.

${ }^{126}$ SUÁREZ FERNÁNDEZ, Enrique IV, p. 52.

${ }^{127}$ Alfonso Franco Silva, Don Pedro Girón, en Señores y señoríos, p. 228.
} 
los condes de Haro y de Alba por parte de Juan II, y Alvar García de Santamaría, vecino de Zamora, por la del rey de Navarra- en realidad tanto el monarca castellano como su privado, el condestable, y el propio príncipe de Asturias estaban ya decididos a plantear la batalla a los infantes ${ }^{128}$. Finalizada la campaña de Murcia, el príncipe regresó a Segovia y en esa ciudad permaneció hasta el 16 de marzo de $1445^{129}$. Salió entonces de Segovia para unirse a la hueste que había reunido don Álvaro. El enfrentamiento, finalmente, tuvo lugar en Olmedo, el 19 de mayo de $1445^{130}$. Los infantes fueron derrotados. El príncipe combatió con dos escuadrones: uno lo mandaba Barrientos con noventa hombres de armas, y el otro Pacheco con otros tantos $^{131}$. El infante don Enrique murió poco después a consecuencia de las heridas que sufrió en la batalla. Su hermano, el rey de Navarra pudo, sin embargo, escapar y refugiarse en Aragón.

La batalla de Olmedo tuvo importantes consecuencias para Pacheco y Girón. El precio impuesto a su colaboración por el mayordomo mayor del príncipe no sólo fue la donación de la villa de Villena, sino también la de otras villas como Sax o Yecla y, lo que era mucho más importante, la concesión del título tan deseado de marqués de Villena. En principio, conviene aclarar que Juan II sólo concedió a Pacheco el título de marqués de esa villa, y no el territorio completo que hasta entonces formaba parte del marquesado. Este personaje poseía ya, desde mayo de 1445 , inmediatamente después de Olmedo, la villa de Jumilla y, tras obtener el título, el monarca le concedería Sax, Villena y Yecla, pero no recibiría el resto de las villas y tierras del antiguo marquesado hasta unos años más tarde. Conviene aclarar este hecho, porque son muchos los historiadores que creen que la concesión del título implicó necesariamente la incorporación de todas las villas y tierras del marquesado, cuando no es así como he tenido ocasión de explicar ${ }^{132}$. Poco después, en las capitulaciones firmadas el 2 de septiembre de 1445 entre Juan II y Álvaro de Luna, de una parte, y el príncipe Enrique y Pacheco de otra, y sobre las que más adelante volveremos, se acordó entre otras cosas que se le daría a éste último una buena compensación si renunciaba a la villa de Ágreda, que pocos meses antes le había concedido el rey ${ }^{133}$. La donación de Ágreda significaba para Pacheco la posibilidad de disponer de una pieza sólida para poderla intercambiar por otra u otras villas que a él pudieran interesarle más. Esta va a ser una constante en su política de acaparar señoríos en territorios muy alejados los unos de los otros, y sobre los que, aparentemente

${ }^{128}$ La tregua en ADF, Catálogo Antiguo, Leg. 49, sin numerar.

${ }^{129}$ SUÁREZ FERNÁNDEZ, Enrique IV, p. 55.

${ }^{130}$ Ibídem, pp. 53 y ss. Del mismo autor Los Trastámaras, pp. 181-183 y Nobleza y Monarquía, p. 123 una buena descripción de la batalla en la Crónica de Juan II, año 1445, cap. VI p. 627. Véase también a este respecto Isabel PASTOR BODMER, Grandeza y tragedia de un valido, Madrid, 1992, I, pp. 67-72.

${ }^{131}$ Crónica del Halconero, cap. CCCXXXVII, p. 463.

${ }^{132}$ Es el error de Luis SuÁREZ FernáNDEZ, Nobleza y Monarquía, p. 122.

${ }^{133} \mathrm{ADF}$, Catálogo Antiguo, Leg. 51, no 3. 
al menos, no podría tener mayor interés, salvo si los utilizaba, como así en efecto haría, como moneda de cambio para conseguir otros, que le permitiesen crear dominios sólidos y homogéneos en una zona determinada. Ya volveremos, más adelante, sobre este aspecto. Ahora, el 13 de septiembre de ese año, el monarca decidía darle la compensación prometida en las capitulaciones ya mencionadas: se le entregarían 1.000 vasallos en la villa de Villena y su tierra, en las de Sax y Yecla y en varias aldeas de la tierra de Alarcón ${ }^{134}$. Pacheco conseguía así finiquitar sus planes, más aún cuando el propio Juan II le había concedido el día anterior el título de marqués de Villena ${ }^{135}$. Pocos días depués un privilegio del príncipe de Asturias, otorgado en Almagro, confirmaba a su privado la donación que su padre le había hecho de Villena, Sax, Yecla y las aldeas de Alarcón ${ }^{136}$. El heredero del trono castellano ordenó después al bachiller Mateo Fernández de Medina del Campo que se desplazase a esas villas, y procediese a redactar un censo que recogiese el número de vasallos que vivían en ellas. El bachiller cumplió escrupulosamente su cometido, y así contó 420 vasallos en las villas de Villena, Sax y Yecla, y los restantes, 580, se escogieron en las aldeas de la tierra de Alarcón ${ }^{137}$. Finalmente, Juan II confirmó las posesiones de Pacheco en un solemne privilegio rodado dado en Toro el 6 de abril de $1446^{138}$.

De esta manera, Villena se incorporaba a los dominios de Juan Pacheco, y en su poder permanecería, junto con Yecla y Sax, hasta el año 1480 en que los Reyes Católicos confiscarán esa villa y otras del marquesado a su hijo Diego López Pacheco. Pero no le había sido fácil a Pacheco apoderarse de Villena. En efecto, hasta el año 1440 Villena había sido la capital, por decirlo así, del gran marquesado al que dio título la propia villa, una extensa demarcación territorial creada a fines del siglo XIII, y que oscilaría a lo largo del XIV y buena parte del XV entre el realengo y el señorío. Se trataba sin lugar a dudas de un apanage, en el sentido francés de este término, es decir un gran estado territorial que la monarquía reservaba para dotar a sus segundones desfavorecidos por las leyes de la herencia ${ }^{139}$. Así se mantuvo, hasta que en el año 1440 Juan II concedió la villa de Villena a uno de sus hombres de confianza, servidor fiel y disciplinado de don Álvaro de Luna, el doctor Pero Yáñez ${ }^{140}$. Este personaje formaba parte de tiempo atrás del grupo de funcionarios de la corte castellana que harían carrera a la sombra y al amparo del condestable. Ya sabemos que Pero Yáñez formaba parte del Consejo Real como hombre de don Álvaro. Cuando en 1440 el

\footnotetext{
${ }^{134} \mathrm{ADF}$, Catálogo Antiguo, Leg. 56.

${ }^{135} \mathrm{El}$ título de marqués de Villena en ADF, Catálogo Antiguo, Leg. $3, \mathrm{n}^{\circ} 18$. Lo he transcrito y publicado en Estudios sobre Ordenanzas Municipales, documento no ${ }^{\circ} 13$, pp. 66-67.

${ }^{136} \mathrm{ADF}$, Catálogo Antiguo, Leg. 31, $\mathrm{n}^{\circ} 5$.

${ }^{137} \mathrm{ADF}$, Catálogo Antiguo, Leg. 3, números 21 y 24.

${ }^{138} \mathrm{ADF}$, Catálogo Antiguo, Leg. 3, no 25.

${ }^{139}$ José Luis PASTOR ZAPATA, Un ejemplo de apanage hispánico: el señorío de Villena (12501445) "Revista del Instituto de Estudios Alicantinos", 31 (1980), pp. 15-40. Véase también sobre Villena mi trabajo ya citado y recogido en Estudios sobre Ordenanzas Municipales, pp. 39-40.

${ }^{140}$ Alfonso Franco Silva, Estudios sobre Ordenanzas Municipales, pp. 37-38.
} 
doctor recibía de Juan II la villa de Villena, segregada para esta ocasión de los territorios que habían formado el marquesado del mismo nombre, el señorío pertenecía entonces al realengo, a pesar de que durante algunos años - de 1420 a 1423 - lo había poseido el infante Enrique de Aragón, a quien se le había otorgado como dote de su esposa, la infanta doña Catalina, hermana de Juan II de Castilla ${ }^{141}$. En 1436, cuatro años antes de que la villa pasase a Pero Yáñez, Juan II se había comprometido a entregar las villas y tierras del marquesado a su primo Juan de Navarra, que las recibiría en concepto de dote para el matrimonio de su hija Blanca con el príncipe de Asturias ${ }^{142}$. EL pacto firmado en Toledo no se cumplió, y Villena continuaría en poder de Juan II hasta ese año de 1440, en que le fue concedida a Pero Yáñez.

El doctor encontraría algunas dificultades a la hora de afianzarse en su nueva posición, porque los partidarios que el rey de Navarra tenía en Villena eran aún numerosos e importantes y sólo esperaban la ocasión propicia para que retornase a su antiguo señor ${ }^{143}$. El propio Juan de Navarra protestó enérgicamente por esa concesión ya que consideraba que la villa le pertenecía, según establecía el acuerdo de 1436, y que por lo tanto esa donación encubría una clara usurpación ${ }^{144}$. Sin embargo, nada pudo hacer para recobrarla. En realidad, la donación de Villena a Pero Yáñez había sido una consecuencia de la coyuntura política de aquellos años ${ }^{145}$. Al parecer, según Pretel Marín, Juan II decidió seguir el consejo de su privado, Álvaro de Luna, y le concedió Villena al doctor a fin de evitar que la villa cayese en poder del rey de Navarra ${ }^{146}$. Desde luego la donación de Villena a Pero Yáñez vulneraba lo acordado en el pacto de Toledo de 1436, y aunque el propio Juan II y su hijo, el príncipe de Asturias, habían prometido al doctor en varias ocasiones que no le sería arrebatada la villa sin la debida compensación, pronto se vió que las circunstancias políticas del reino hacían imposible el cumplimiento de tal promesa. El propio Pero Yáñez, antes de morir, había pedido al príncipe Enrique, a quien correspondía legalmente en virtud de la dote de su esposa la villa y el marquesado, que no le quitase Villena ni a él, ni tampoco a sus herederos, al menos sin una adecuada compensación ${ }^{147}$. El viejo doctor, sin embargo sabía que perdería Villena a pesar de las promesas reales y principescas al respecto. Yáñez conocía de primera mano lo que estaba ocurriendo en la corte, y sabía desde luego que nada podía hacer frente a la voracidad del privado del príncipe, que había puesto los ojos en esa villa y en

\footnotetext{
${ }^{141}$ Ibídem, p. 40.

${ }^{142}$ Ibídem, p. 40.

${ }^{143}$ Aurelio PRETEL MARÍN, Algunas acciones militares de Albacete y su comarca en las luchas de los infantes de Aragón (1421-1444), "Al-Basit. Revista de Estudios Albacetenses", 2 a época, VII/10 (abril de 1981), p. 33.

${ }^{144}$ Alfonso FranCo Silva, Estudios sobre Ordenanzas Municipales, pp. 43-44.

${ }^{145}$ Esta es la opinión de José María SOLER GARCÍA en La donación de Villena al Dr. Periáñez en 1440, Studia Histórica in honore Vicente Martínez Morellá", Alicante, 1985, p. 437.

${ }^{146}$ Aurelio Pretel MARÍn, Algunas acciones militares, p. 33.

${ }^{147} \mathrm{El}$ documento en ADF, catálogo Antiguo, Leg. 56. Veéase también José María SoLER, art. cit., p. 438.
} 
el propio marquesado desde hacía algún tiempo. Su fallecimiento, por fortuna, le impidió ver el despojo que el príncipe y Pacheco perpetraron contra sus hijos. Su muerte, en cualquier caso, precipitó los acontecimientos. Ya hemos visto cómo en el acuerdo pactado con el condestable, en enero de 1444, éste último le había prometido que trataría de que el monarca le cediese Villena. Dos meses mas tarde era el propio Juan II, quien presionado por su privado y por su hijo, le concedía Villena a Pacheco. En este albalá el monarca pasaba por alto los derechos que a Villena podrían tener los herederos del doctor ${ }^{148}$. En realidad, el rey no podía hacer otra cosa ante la continua insistencia del privado de su hijo. A la desesperada, el monarca llegó incluso a ofrecer a Pacheco, en lugar de Villena, 700 vasallos en tierras de Sevilla o de Córdoba. Nada, sin embargo, pudo hacerse. El despojo de Villena a los herederos de Yáñez comenzó cuando el príncipe, el 21 de noviembre de 1444, en un albalá fechado en Murcia, aprovechaba la desaparición del doctor para reclamar para sí mismo la villa, "por ser lugar del marquesado de Villena e me pertenesçe por razón de la dote que me fue prometida al tiempo que se concertó mi casamiento con la princesa, mi muy cara e amada mujer"149. En realidad, cuando firma este albalá, don Enrique y su mayordomo mayor habían ocupado por la fuerza, tras un duro asedio, la villa y fortaleza de Villena. Los herederos del doctor Pero Yáñez nada pudieron hacer frente al poder que había alcanzado en ese momento el heredero del trono de Castilla. Se le prometió una compensación a Juan de Ulloa, primogénito del doctor, por la pérdida de la villa. El propio príncipe juró y prometió ante su camarero mayor, Pedro Girón, que así lo haría ${ }^{150}$. Incluso Pacheco y don Álvaro se comprometieron a conseguir del monarca una reparación para Ulloa. Las promesas jamás se cumplirían. El príncipe y Juan Pacheco no habían tomado Villena de forma pacífica, sino por la fuerza, despojando a los Ulloa de la posesión de la villa. La usurpación estaba hecha. El final ya lo conocemos: el príncipe había ocupado la villa para entregarla a su favorito, que tomaría posesión de ella después de la derrota de los aragoneses.

Pero no fue sólo Pacheco quien ganó señoríos tras Olmedo; su hermano Girón no iba a ser menos, y así se le dio un premio extraordinario, nada menos que el maestrazgo de la orden militar de Calatrava ${ }^{151}$. El cronista Palencia piensa que ambas donaciones - la del marquesado y la del maestrazgo- constituían el precio que don Álvaro se veía obligado a pagar a fin de conseguir la aprobación de Pacheco, y por tanto del príncipe Enrique,

${ }^{148} \mathrm{He}$ publicado este documento de Juan II en Estudios sobre Ordenanzas Municipales, doc. $\mathrm{n}^{\mathrm{o}}$ 11, pp. 62-64.

${ }^{149} \mathrm{ADF}$, Catálogo Antiguo, Leg. 51, $\mathrm{n}^{\mathrm{o}} 3$.

${ }^{150}$ Ibídem. He publicado el documento en Estudios sobre Ordenanzas Municipales, pp. 65-66.

${ }^{151}$ Crónica de Juan II, 1445, p. 628. El nombramiento de maestre se produjo el 19 de septiembre. Ver a este respecto, F. UHAGón, Ordenes Militares, Madrid, 1898, Ana VIÑA, Morón y Osuna en la Baja Edad Media, Ecija, 1991, p. 17. Girón tomó posesión efectiva a fịnes de diciembre de 1445 , J. O'CALLAGHAN, Don Pedro Girón, Masters of Calatrava, "Hispania", 83 (1961), p. 351 y ss., la Crónica de Juan II, 1445, cap. XIX, p. 636, y la tésis doctoral de Javier AGUADO, El ascenso de un linaje castellano en la segunda mitad del siglo XV: Los TellezGirón, condes de Ureña, Universidad Complutense de Madrid, 1990. 
para dar luz verde a su proyecto de casar a Juan II, viudo reciente de María de Aragón, con la infanta Isabel de Portugal ${ }^{152}$. No hubo problema alguno en la donación del título del marqués de Villena, y era una concesión muy importante porque se trataba de un título que hasta entonces sólo lo habían disfrutado miembros de la familia real. En cambio, sí presentó algunos inconvenientes la donación del maestrazgo de Calatrava que pronto, sin embargo, se resolvieron. Según Palencia, se había pasado por alto al maestre Juan Ramírez de Guzmán y a don Fernando Padilla, clavero de la orden, que había sido elegido maestre por algunos comendadores, y tampoco se había tenido en cuenta a don Alfonso, hijo del rey de Navarra, a quien el papa había concedido esa dignidad poco antes, y que probablemente se hubiese podido hacer con ella si su padre no hubiese sido derrotado en Olmedo ${ }^{153}$. Si el maestrazgo de Calatrava fue el mejor regalo que recibiría Girón tras Olmedo, no fue, sin embargo, el único. Inmediatamente después de la derrota de los aragoneses, y antes de conseguir el maestrazgo, Girón había recibido importantes prebendas. En efecto, el 25 de junio de ese año, su protector, el príncipe Enrique, le concedió tres poblaciones situadas en tierras de Valladolid: Urueña, Tiedra y Pobladura, punto de partida del gran núcleo señorial del futuro linaje en tierras castellanas ${ }^{154}$. Un mes más tarde recibiría las tercias de la villa de Arévalo y su tierra ${ }^{155}$. De esta manera, el segundón de los Pacheco conseguía también convertirse en señor de vasallos, a costa del despojo de los vencidos en Olmedo. Pero a pesar de la importancia de estas donaciones, ninguna de ellas podía compararse con la elección de maestre de Calatrava, pues el control de esta orden militar le proporcionaría un formidable poder militar y económico que Girón va a utilizar en el futuro, con bastante éxito por cierto, para su exclusivo beneficio personal y el de su familia. En cualquier caso, al desaparecer los infantes de Aragón y al haber contribuido de manera importante a su derrota, el poder del príncipe, y el de estos dos ambiciosos hermanos, crecería considerablemente hasta el punto de que a partir de ahora cualquier decisión que se tomase en el reino, o cualquier problema que se presentase, debería contar necesariamente con su aprobación y respaldo.

\footnotetext{
${ }^{152}$ Palencia, Crónica de Enrique IV, Libro I, cap. VII, pp. 23 у 24.

${ }^{153}$ Ibídem, Libro I, cap. X, p. 30. La disputa por el maestrazgo de Calatrava la ha estudiado muy bien Joseph O'CALLAGHAN, art. cit., pp. 354 y ss., y, sobre todo, Emilio CABRERAMUÑOZ El acceso a la dignidad de Maestre y las divisiones internas de las Ordenes Militares durante el siglo XV, recogido en su libro Feudalismo y Señoríos al Sur del Tajo (siglos XIII al XV), Córdoba, 2007 , en especial pp. 342-345, con abundante y reciente bibliografía.

${ }^{154}$ La donación de estas villas en Archivo Histórico de la nobleza Española (Toledo), Sección Osuna, carpeta 2 , números 3 y 4.

${ }^{155}$ Javier AGUADO y Remedios MORÁN, Papel del marqués de Villena en la formación del señorío de Osuna, "Congreso de Historia del señorío de Villena", Albacete, 1987, p. 19.
} 


\section{APÉNDICE DOCUMENTAL}

Sin fecha. Hacia 1442

\section{El infante don Enrique, el almirante, el conde de Benavente y el adelantado Pedro Manrique piden a Juan II que no enajene más bienes de la Corona.}

ADF, Catálogo Antiguo. Sin numerar.

B. Publicado en Codoin, IIV, pp. 366-367.

Muy alto prinçipe e muy poderoso rey e sennor.

Los vuestros muy omildes seruidores infante don Enrique, e Almirante de Castilla, e conde de Benavente, e Adelantado Pero Manrique por nos, e en nombre de los otros condes e perlados e caualleros que en Valladolid estouieron en seruiçio de Dios e vuestro e bien de vuetros regnos, con muy omilde e devida reuerençia besamos vuestras manos e nos encomendamos en vuestra merçed, a la qual plega saber que a nuestra notiçia vino en commo vuestra sennoría ha fecho e fase de vn anno a esta parte muchas merçedes de villas e logares e de juro de heredad e de por vida a muchas personas, e asy mesmo que vuestra sennoría ha dado e da muchos lugares e tierras de vuestras çibdades, lo qual es muy grand dapno e destruyçión de vuestros regnos, cá commo vuestra sennoría sabe ay pocos lugares en vuestros regnos que non estén dados e enajenados e en más enajenar [no se entiende] en desapropiar e quitar las tierras e lugares a vuestras çibdades seria perder del todo vuestro patrimonio e vuestro regno. E demás desto sabe vuestra merçed que las rentas ordinarias de vuestros regnos non alcançan a vuestros gastos e merçedes ordinarias que fasta el dicho tiempo son fechas con muy grandes cuantias de maravedíes, e sy después acá vuestra sennoría ha fecho o fase otras merçedes a personas, esforçado es que continuadamente vuestra altesa aya de echar pedidos e monedas a vuestros vasallos e que del todo se pierden allende de quanto están destruydos e desipados e deue vuestra sennoría acatar que el thesoro del rey es en su pueblo, e sy el pueblo vuestro es destruydo vuestro thesoro se pierde. Por ende, muy omillmente soplicamos a vuestra altesa que le plega de acatar las merçedes que fase e por qué las fase, e quando algunas vuestra sennoría entendiere que se deuen faser las quiera faser con consejo e acuerdo de los de vuestros regnos, e de los procuradores de las cibdades e villas dellos, en lo qual vuestra sennoría fará lo que es seruiçio vuestro e grand prouecho de vuestros regnos porque en ello aya en él reparo e remedio que cumple a seruiçio de Dios e vuestro e bien público de vuestros regnos.

E desto pedimos testimonio al muy esclaresçido sennor nuestro sennor. Dios ensalçe vuestra corona e conserue vuestra persona e vida a su seruiçio amén. 
¿1441? julio.

Delimitación de los términos de Villanueva de Alcaraz, Lozuza, Munera y el Bonillo.

ADF, Catálogo antiguo, Leg. 56.

Sennor conpadre:

Commo mi deseo es en todo seruir a Pacheco, mi sennor, lugo (.sic) commo resçebi la carta de su merçed e la vuestra procuré de partir de mi casa a fazer aquella limitaçion de los terminos, non tanto por las mantequillas e miel e cabritos commo por faser lo conplidero a su seruiçio, avnque algund tanto me causó abreuiar la partida el muncho salario que me mandastes dar, que en mi fe vos juro que en seys dias que estoue en Alcaras con vn escriuano que leué, el qual sy non leuara yo fuera maltraydo, más gasté de CCC, asi que del salario, descontada la costa, fago alcançe dos marauedis e medio, e andemos a buena cuenta entrar con dos salir con vno, porque non aya yerro. Fynalmente partí para faser la dicha limitaçion primero dia de jullio, e commo llegare a Alcaras presenté la dicha carta del prinçipe nuestro sennor e el poder de mi sennor Pacheco, e en cámara fue obedesçida la dicha carta, e al conplimiento sennalaron a Iohan Sanches de Pedro Munnos, alcalde en la dicha limitaçion, para yr a faser la dicha limitaçion comigo, el qual es tal omme que comigo nin con otro non se conuernía a dar términos algunos e de la opinion del bachiller Iohan Sanches de Bustamante, e de él e de mí fue resçebido el juramento que el dicho sennor prinçipe mandó por su carta, pero non le fue dado poderio; esto porque sy nos, él e yo, concordásemos en los terminos, non valiese cosa de lo que fisiese. E esto fecho salimos a continuar la dicha limitaçion açerca de Villanueua, e çertifícovos en mi fe que del término que oy poseen en esta villa de Villanueua, más quitaua de la meytad e el más largo término que sennalaua era non media legua, e a otros logares non dos trechos de ballesta, e asi por consiguiente en los otros logares del dicho mi sennor Pacheco, avnque por ser más apartados de Alcaras los alargaua algund tanto. E yo veyendo mostrar en todo tanta parçialidad, sennalé los terminos por otros logares muy justos e rasonables, los quales porque en ellos entendades vos escriuo:

Villanueua

El primer mojon que fuese asentado en vn alcor que está çerca la puente la Reyna, e otro en vn risquillo donde entra el camino e el alcor ayuso fasta vn mojon que esta en la defesa del Palomar, e dende adelante por la cunbre a ojo del Palomar, e el mojon adelante fasta dar en Guadarmena e Guadarmena ayuso fasta donde se juntan el arroyo de Villanueua e el rio arriba fasta el término de la Orden.

E desde la cunbre del alcor de la puente la Reyna la cunbre adelante fasta el piçorro del Quintanar, e de alli fasta la cabeça Ruuia que está en la defesa de la Pouedilla, e de allí a las carrascas de Martin Sanches que están la fuente Martin Peres, e de allí a la fuente del Sotillo e la senda adelante fasta dar en la senda de los Golondrynos fasta Moheda Alta e la can nada Honga ayuso e al Charcón e luego al Tarancón e a la Madriguera, e la cannada Fonda ayuso fasta dar en la Orden.

Los quales dichos terminos son justos e rasonables e tales que si alguna cosa les es quitado les verná danno, por quanto a logares a que fase la Orden non ay de término vn quarto de legua e al más largo es vna legua e non más. 
(fol. Iv) Bonillo

Sennalauan el vn mojon al nauajo el Peral e otro en nava la Ysla e a la fuente de Susanna e la cannada ayuso a naua las Ensebras e a la cabeça la Naua e al poso el Picado, e la cannada ayuso fasta la pena (sic) el Arconçillo e al pozo del Almoranad e el carril viejo adelante fasta el puerto e al nauajo el Robre e alojo Bernaldo e al prado Mingoqueles e a los Gayunares e a la cabeçuela don Garçia e a la cannada Mal Calçado e al poso, la Papalua, e que torne al nauajo el Peral.

E estos terminos a lo más largo es vna legua de término, e en todo eramos conuenidos saluo que non querían que fuese entre terminos la fuente de Susanna, synon que tomase çient pasadas fasa (sic) el Bonillo, e en aquella fuente los veçinos del Bonillo abeuran (sic) sus ganados e tienen sus heredades e sus chocas (sic) allí para labrar e continuan allí lo más del anno, e en les quitar esto era quitarles la vida e faserles perder, porque desde allí los lieuan a Alcaras e fatigan asy por los montes los cauallos de la sierra commo por qualesquier cosas que allí acaescan, asy que es rason e justiçia que les sea dado, espeçialmente que todos los que alli labran diezman en el Bonillo de muncho tienpo aca.

\section{Munuera}

Sennalauanle el primero mojón al miron de los Loseros e al alcor del atalayuela, e al atalayuela el Pedregal e a los tajadales al mojon que está puesto en el camino de Socuelamos e a las Salegillas que estan en las cabeçadas del aro de Juan Mateo, e al vallejo la Madera e a la vertiente de la can nada de Yuannnes Ynnego e la vertiente adelante a la carrasca que está en el camino del Bonillo que tiene vna piedra en los forcajos, e al mojón de la cabeça de Naualcudia e a Nauaquemada e a vn robre que está en el camino que va al molino e al paridero viejo e a la fuente Llobo e a los Torneruelos e al mojón que está camino de Losusa e a cabeça Ruuia e al poso de Lechina (sic) e al atalayuela de Lenchina e al çerrillo de la losa la Trayçion e al çerrillo Terçero e a la losa Miguell Viejo e al Ensogadilla e a la cabeça el Aguila e la vertiente del çerro el Gato e a la Coxcojosa e al çerro Maryn e a la losilla Lonbardo e a la cannada el Perro arriba e a la losa Cauada e tornar al miron de los Loseros.

E estos términos a lo más largo es vna legua saluo en vna defesa que ellos han por preuillejo que es poco más de vna legua, e esto le sennalé porque tienen la dicha defesa preuillegiada, la qual los de Alcaras los querrian perturbar, e por esto e porque quieren que entr'el Bonillo e Munuera e Losusa que son tan çercanos el vno del otro que les quede término entre medias, sy ay dos leguas la vna, e esto es syn rason porque del Bonillo a Munera son dos leguas pequennas e si entre medias ouiesen de tomar terminos non les quedaria nada, e asi por consiguiente entre Munera e Losusa, e par tanto çertifícovos que los yo sennalé justamente.

\section{(fol. 2r) Losusa}

Sennalaua el mojon primero de la cueua el Lobo a la cabeça el Tocon e al poso de Gil de Moya e dende al puerto Mingote e a la cabeça del Tamaral e a la fuente del Puerco e al ojuelo del Reuellado e el vallejo arriba fasta camino viejo, e asi fasta do crusa el camino real con la senda de las Torres e a la sima de los çerros de Valaçote e a las atalayuelas de Lara e al atalaya Martin Negrillo e a la losa de Barrax e a la losa las Gualdas e a la losa el Romeral e a la cabeça Çamaçon e a la atalaya de Lenchina e al poso e al mojon del camino de Munuera e a la naua don Gorgorio e tornar a la cueua del Lobo.

Lo qual vos çertifico ser los dichos términos justamente limitados, e non sallí en cosa del término por donde los que alli tienen heredades diesman en la dicha 
Losusa. E pues que este término sienpre touieron por sy, non es rasón que agora sean penados de la más parte d'ellos.

E todos estos terminos en mi conçiençia eran e son muncho justos e rasonables, e tales que ninguno más non se pudiera más justificar con la dicha çibdad. E en algunos terminos d'estos nos concordamos el dicho Juan Sanches e yo, saluo que me apartó e dixo secretamente que platicasemos asi los dichos terminos e platicados que lo notificasemos a la dicha çibdad, que en otra manera él non asentaria cosa alguna e que creia que desque la dicha çibdat lo viese que le mandara que lo acabase, en la qual rason presumi que le era asy mandado por el dicho conçejo. E sobre esto fuemos a la dicha çibdad e fise vn acto en cámara, el qual respondieron asas feamente segund verés en el testimonio que alla enbío. Yo vos pido por merçed que tengades orden cómmo les sea dado a entender este fecho, ca podés ser çierto que los que más fazian e se oponian contra ello e más se mostrauan contrarios eran el bachiller lohan Sanches de Bustamante e Garçia Fernandes de Ballesteros, ca yo les oy saliendo de cámara quando presenté la carta del dicho sennor prinçipe e la obedeçieron, la qual obedesçio el bachiller Guerrero en nonbre del conçejo, que dixo asi el bachiller de Bustamante al otro "Non es bien eso, bachiller, que otras cosas se auian de fazer antes del conplimiento, e en mal ora sea fecho que fagades vos las cosas non conplideras al pro comun d'esta cibdad". Lo qual ovieron e pasaron asas razones entre ellos des pues que fuy salido de camara e mandaron al escriuano de su secreto que non tornase las cartas originales nin me las nunca quiso dar, segund lo qual podés ver sy estauan aparejados a faser e mostrar contrario a la presona que lo tal ouiera de fazer; sy non leuara escriuano e si non oviera tomado los traslados de las cartas, perdonar pudiérades que non se pudiera alçar testimonio. E avn a la sazón qu'el dicho testimonio alçé, dixo el dicho bachiller de Bustamante estas rasones: "Diego Sanches podés ser çierto que yo non puedo falesçer a esta çibdad en todo e en guardar el pro comun d'ella, por ser mi naturaleza d'ella, e por ende non vos deués quexar porque yo ordene las respuestas contra vos, pues qu'el bachiller Guerrero, que es letrado del conçejo, non quiere ordenar cosa". A lo qual yo satisfize que pues que la carta del sennor prinçipe non cunplia, que tanto me daua que respondiese él commo otro qualquier, e otras cosas que al caso conuinian. E por estas rasones podés entender se concluyen las rasones que alla fablé con mi sennor Pacheco e con vos, non enbargante que yo le dixe de parte de su merçed lo que me escriuio en su letra que fablase al dicho bachiller quando el que comigo $(f o l .2 v)$ pusiesen para la dicha limitaçion e yo nos non couiniésemos a ella, que tomase por terçero al dicho bachiller non dando a entender que por mí era pedido, e non curó d'ello, antes me dixo: "Por Dios a mí plaze de ser terçero entre vosotros, pero aués de tener por dicho que non saldré de la sustançia que tiene ordenada Juan Sanches de Pedro Munnos". E yo le respondí que sy aquello avia de pasar, que non aviamos de menester terçero; e asi nos despidiemos. E desqu'el dicho conçejo non quiso conplir nin cunplió lo contenido en la dicha carta del dicho sennor prinçipe, yo alçé testimonio e enplasé al conçejo e es justo el dicho enplasamiento, por quanto non dieron poder a la presona que comigo sennalaron segund el tenor de la carta del dicho sennor prinçipe al tienpo que fue sennalado, lo qual fisieron a mal fyn e maliçiosamente, porque si él e yo nos concordasemos non valiese cosa lo que fisiesemos, e asy lo mostraron en el escripto que presentaron, porque suplicaron de la limitaçion qu'el dicho Juan Sanches auia fecho. E tanbien enplasé al dicho Juan Sanches de Pedro Munnos que comigo fue puesto por limitador, el testimonio de lo qual vos enbío porque sobre ello fagades lo que cunple en el caso. Paresçeme que este conçejo e ofiçiales d'esta çibdad non han voluntad de dar términos algunos a estos logares avnque se porfíe con cartas del dicho sennor prinçipe, e lo que me paresçe que en esto se deue faser es que los términos viniesen de alla limitados por 
carta de su merçed por los logares que vos escriuo, los quales non dannan en cosa alguna a la dicha çibdat, en espeçial quedando los terminos comunes commo quedan; e en la tal carta que venga que les manda por primera e segunda e terçera jusion que syn le más consultar lo cunplan asy, poniendoles grande pena e el enplazamiento para que parescan presonalmente, ca en otra manera, segund lo que d'ellos entiendo, todo es gastar tienpo en balde.

Otrosi con Sancho Lopes de Jahen fablé sobre vuestra hermandad de Alcaras, el qual me dixo qu'el escriuano non tenia sacada la conuenençia e qu'él se ternía e tiene cargo de la sacar e enbiar a Belmonte.

De vuestras yeguas vos puedo desir que son paridas tres potros e vna fenbra; que de las vacas, demás que salieron vasías, el veserro de antanno se comió el lobo, e esto creo lo fiso la parte que yo en ellas he. Sy por ventura algunas prouisiones enbiáredes sobre el caso de suso, e el cargo de aquellas mandáredes a mí aca tomar, plegavos acreçentar en el salario porque la cuenta venga çierta. $=$

Sobre lo que de suso se contiene, escriuo a mi sennor Pacheco corta escriptura porque non enoje. Plegavos de le desir todos estos fechos cómmo van. Otrosi, sennor conpadre, algunos d'estos vasallos de Pacheco, mi sennor, se quexan disiendo que non enbargante que son agrauiados en algunos pleitos que tractan ante sus alcaldes, que non suplican nin apellan e se dexan fatigar por non yr a Corte a se presentar e seguir la apellaçion, e que si posible fuese se diese aca jues. Yo vos pido por merçed que si vos entendés que se puede faser e a vos plase d 'ello, me enbiés vuestro poder para que por vos pueda oyr por jues mayor o en la manera que vos entendades que cunple, non enbargante que en esto non me es ynterese saluo doliendome de sus trabajos. E sennor conpadre, Dios nuestro sennor conserue vuestra presona e estado commo deseades. De Villanueua a XVI de jullio. Que es a vuestro mandamiento e fará lo que mandáredes Diego Sanches (rubricado).

Sennor.

Sepa vuestra merçed que para faser la limitaçión de los términos entre Alcaras e los logares de vuestra merçed, yo fuy a la dicha çibdat e presenté en cámara la carta del sennor prinçipe, la qual obedeçieron e sobre el conplimiento pasaron asas rasones entr'el bachiller de Bustamante e el bachiller Guerrero, las quales porque vuestra merçed non se enoje con larga escriptura yo escriuo a Gonçalo Sanches para que lo fable a vuestra merçed, e tanbien le escriuo lo que me paresçe que se deue faser sobre ello e las prouisiones que se deuen auer; por merçed vos pido que mandedes dar en ello breue espediçion, ca estos ofiçiales d'esta çibdat non tienen en voluntad de lo faser syn premia, en espeçial el bachiller de Bustamante, que yo çertifico a vuestra merçed que aquel se mostró más contrario en todo, con el qual fablé desque me non conuine con el que puso la çibdat que fuese terçero entre nosotros, e me dixo que sy yo queria que la limitaçión pasase segund estaua sennalado por parte de la çibdat que le plasia, pero que en otra manera non era neçesario. Lo qual escriuo a vuestra merçed porque sepades lo que en él tenés. E nuestro sennor Dios conserue vuestro estado e onor.

Sennor. Vmilde seruidor de vuestra merçed que besa vuestras manos. Diego Sanches (rubricado). 
1446, junio, 4. Segovia.

Traslado del privilegio de Juan II, por el que confirma a Juan Pacheco la donación de la villa de Utiel y de los lugares de Villanueva de Alcaraz, Lozuza, Munera y El Bonillo. Inserta las donaciones de 1440.

ADF, Catálogo Antiguo, leg. $4, \mathrm{n}^{\circ} 5$.

En la noble çibdat de Segovia. Sábado quatro días del mes de junio anno del nasçimiento del nuestro sennor Jhesu Xrispto de mill e quatroçientos e quarenta e seys annos antel bachiller Andrés de la Cadena, alcalde en la dicha çibdat por nuetro sennor el príncipe, en presençia de mi Diego Rodrigues, escriuano público a la merçed del dicho sennor prínçipe en la dicha çibdat, e ante los testigos de yuso escriptos, paresçió presente el sennor don Johan Pacheco, marqués de Villena, mayordomo mayor del dicho sennor príncipe e presentó antel dicho alcalde e fiso leer por mí el dicho escriuano vna carta de preuillejo de nuestro sennor el rey escripto en pargamino de cuero rodado e sellado con su sello de la poridad en plomo pendiente en fylos de seda a colores segúnd por él paresçerá, el thenor del qual es este que se sigue.

En el nombre de Dios, padre e fijo e espiritu santo, que son tres personas e vn solo Dios verdadero que biue e reyna por siempre jamás, e de la bien aventurada virgen gloriosa Santa María, su madre, a quien yo tengo por sennora e por abogada en todos los mis fechos, e a onra e seruiçio suyo e de la corte çelestial, e del bien aventurado apóstol sennor Santiago, luz e espejo de las Españas, patrón e guardador de los reyes de Castilla. Porque rasonable e convenible cosa es a los reyes e prinçipes faser graçias e merçedes a los sus súbditos e naturales e acreçentarlos en sus onras e estados, espeçialmente aquellos que lealmente e con pura voluntad los syruen e aman su seruiçio, e el rey o el prínçipe que la tal merçed fase ha de catar en ello tres cosas, la primera qué merçet es aquella que le demanda, la segunda quien es aquél que ge la demanda e commo gela meresçe o puede meresçer, la terçera qué es el pró o el danno que le dello puede venir. Por ende, yo acatando e considerando todo esto quiero que sepan por este mi preuillejo rodado o por su traslado abtorisado en manera que faga fe todos los que agora son o serán de aquí adelante de commo yo don Johan por la graçia de Dios, rey de Castilla, de León, de Toledo, de Gallisia, de Seuilla, de Córdoua, de Murçia, de Jahén, del Algarbe, de Aljesira e sennor de Viscaya e de Molina, reynante en vno con el prinçipe don Enrique, mi muy caro e muy amado fijo primogénito heredero en los reynos de Castilla e de León, vy vna mi carta escripta en papel firmada de mi nombre e sellada con mi sello de çera de la poridad que es fecha en esta guisa.

Don Johan por la graçia de Dios, rey de Castilla, de León, de Toledo, de Gallisia, de Seuilla, de Córdoua, de Murçia, de Jahén, del Algarbe, de Algesira e sennor de Viscaya e de Molina, a vos el mi chançiller e notarios e a los otros mis ofiçiales que estades a la tabla de los mis sellos salud e graçia, sepades que yo dí vna mi carta firmada de mi nombre e sellada con mi sello, el thenor de la qual es este que se sigue.

Don Johan por la graçia de Dios, rey de Castilla, de León, de Toledo, de Gallisia, de Seuilla, de Córdoua, de Murçia, de Jahén, del Algarbe, de Algesira e sennor de Viscaya e de Molina. Acatando los buenos e leales seruiçios que Johan 
Pacheco, mi donsel e vasallo, fijo de Alfonso Telles Gyrón, mi vasallo, me ha fecho e fase de cada día asy a mí commo al prínçipe don Enrique, mi muy caro e muy amado fijo primogényto heredero en los mis regnos, entendiendo que lo fará e contynuará asy de aquí adelante, e en alguna enmienda e remuneraçión de los dichos seruiçios e porque sea enxenplo a otros que siruen bien e lealmente asy a mí commo al dicho prínçipe, mi fijo, por la presente do liçençia e abtoridad, otorgamiento e espreso consentimiento al dicho prínçipe, mi fijo, para que non enbargantes qualquier proybiçiones, vedamientos, ynibiçiones, condiciones, modos e cláusulas e defendimientos e otras qualesquier cosas de qualquier natura e efeto e calidad e misterio que en contrario sean o ser puedan, asy las contenidas en las cartas de la graçia e merçed e donaçión que yo fise e dy al dicho prínçipe, mi fijo, de la çibdat de Alcaras e de su tierra e término e jurediçción commo de la villa de Vtyel e su término e en otra qualquier manera e por qualquier cabsa o rasón que sea o ser pueda, ni otrosy non enbargante otro qualquier ostáculo e ynpedimiento de fecho o de derecho que lo enbargar o perjudicar podiese al dicho prínçipe, mi fijo, libremente pueda dar e dé al dicho Johan Pacheco por juro de heredad para syenpre jamás para sy e para sus herederos e subçesores e para quien el quisiere e por bien touiere la dicha villa de Vtiel con su tierra e término e dystrito e justiçia e jurediçión alta e baxa, ceuil e criminal e mero e misto ynperio e rentas e pechos e derechos e penas e calonnias e con todas las otras cosas pertenesçientes al sennorío de la dicha villa e su tierra, de la qual yo oue fecho merçed al dicho prinçipe, mi fijo, en que dis que ay fasta tresientos vasallos. E así mesmo pueda apartar e aparte de la jurediçión e sennorío e subgeçión e término de la dicha çibdat de Alcaras los lugares e aldeas de Villanueva de Alcaras e del lugar de Vonillo e del lugar de Lesusa e del lugar de Munera, en los quales dis que ay fasta quinientos vasallos, e los pueda dar e dé por juro de heredad para siempre jamás commo suso dicho es al dicho Juan Pacheco todo esto e cada cosa dello fasta en quantía de ochoçientos vasallos asy en la dicha villa commo en los dichos lugares, e que los pueda dar e dé con todos sus términos e dystrito e justiçia e jurediçión çeuil e criminal, rentas e pechos e derechos e penas e calomnias e con todas las otras cosas e cada vna dellas pertenesçientes al sennorío de los dichos lugares e de cada vno dellos, e le pueda faser e faga merçed e graçia e donaçión e remuneraçión pura, propia, perfeta e non reuocable para sienpre jamás de todo lo suso dicho e de cada cosa e parte dello, e del sennorío e propiedad tenençia e posesión dello e de cada cosa e parte dello, e gelo dar e entregar e le dar e dé poder e abtoridad e facultad para lo entrar e tomar e tener e poseer e enajenar e faser dello e de cada cosa dello commo de cosa suya propia libre e quita, e le dar e faser e otorgar sobre ello su carta o cartas con qualquier cláusulas e firmesas e juramentos, e yo por la presente fago merçed e graçia e donaçión de todo ello e de cada cosa e parte dello al dicho Juan Pacheco, e que lo do por juro de heredad para syenpre jamás según e por la forma e manera quel dicho prínçipe mi fijo gelo diere e otorgare, e ynterpongo mi decreto e abtoridad real a todo ello e cada cosa e parte dello para que vala e sea firme, estable e valedero para syenpre jamás, non enbargantes qualesquier leyes, fueros, derechos, ordenamientos, estylos, costunbres, fasannas e toda otra cosa así de fecho commo de derecho de qualquier natura, vigor, efeto, calydad e misterio que en contrario sea o ser pueda aunque fuese tal de lo qual aquí deuiese ser fecha espresa e espeçial mençión, ni otrosy non enbargantes las leyes que disen que las cartas dadas contra ley o fuero o derecho o ordenamientos deuen ser deuen ser [sic] obedesçidas e non conplidas aunque contengan qualesquier cláusulas derogatorias saluo por cortes, las leyes e fueros e derechos he ordenamientos que yo de mi propio motu e çierta çiençia e propio motu e poderío real absoluto dispenso contra todo ello e contra cada cosa e parte dello e lo abrogo e derogo e alço e quito e amueuo en todo e por todo en quanto 
a esto atanne o atanner puede en indugo contra todo ello e contra cosa e parte dello mi plasentería e perfeta dispensaçión e suplo qualesquier defetos en caso que algunos ouiese o aya o ayan ynteruenido o yntervengan, e asy mesmo otras qualequier cosas asy de sustançia commo de solepnidad o en otra qualquier manera neçesarias e conplideras e prouechosas de se suplir para validaçión e corroboraçión de todo lo suso dicho e de cada cosa e parte dello, e alço e quito e amuevo e he por non puesta la tal proybiçión e defendimiento, vedamiento e ynybiçión de alienación e condiçión e modo e cláusulas derogatorias e otras qualesquier que en contrario de lo susodicho e de qualquier cosa e parte dello sea o ser pueda, e do e otorgo e trespaso en el dicho Johán Pacheco e en sus herederos e subçesores la tenençia, posesión, propiedad e sennorío de todo lo susodicho e de cada cosa e parte dello para syenpre jamás, e le do poder, abtoridad e facultad para lo entrar e tomar syn pena e syn calopnia alguna por sy e por otros por él segund e por la forma e manera quel dicho prínçipe, mi fijo, gelo diere e otorgare, e otorgo e prometo por mi fe real de lo ansy guardar e conplir e mandar guardar e conplir e de non yr ni venir ni consentyr ni permityr ni dar lugar que persona ni personas algunas de qualquier estado o condiçión preheminençia o dignidad que sean vayan nin pasen contra ello nin contra cosa alguna nin parte dello agora nin en algund tiempo nin por alguna manera nin por cabsa nin rasón que sea o ser pueda. E mando al dicho prinçipe, mi fijo, e a los ynfantes, duques, condes, ricos ommes, maestres de las órdenes, priores, comendadores e subcomendadores, alcaydes de los castillos e casas fuertes e llanas e a los del mí consejo e oydores de la mi abdiençia e alcaldes e notarios e alguasiles e otras justiçias e ofiçiales qualesquier de la mi casa e corte e chançellería, e a los conçejos e vesinos e moradores de la dicha villa e de los dichos lugares e de cada vno dellos, e a todos los conçejos e alcaldes, alguasiles, regidores, caualleros, escuderos e ommes buenos de todas las çibdades e villas e lugares de los mis regnos e sennorios, e otras qualesquier personas mis súbditos e naturales de qualquier estado o condiçión, preheminençia, dignidad que sean, o a qualquier o a qualesquier dellos que lo guarden e cumplan e fagan guardar e conplir bien e conplídamente en todo e por todo segund que de suso se contiene, e que non vayan nin pasen nin consientan yr nin pasar contra ello nin contra cosa alguna nin parte dello agora nin en algund tiempo nin por alguna cabsa nin rasón nin color que sea o ser pueda, e que sobre esto nin sobre cosa alguna nin parte dello non me requieran nin consulten nin atiendan otro mi mandamiento nin segunda jusyón, que mi merçed e voluntad es que esto se faga e cumpla todo asy. E los vnos nin los otros non fagades ende al por alguna manera sopena de la mi merçed e de priuación de los oficios e de confyscaçión delos bienes de los que lo contrario fesieren para la mi cámara. E sobre esto mando al mi chançiller e notarios e a los otros que están a la tabla de los mis sellos que den e libren e pasen e sellen al dicho Johan Pacheco mi carta e preuillejo la más firme e bastante e con las mayores firmesas e cláusulas derogatorias que le conplieren e menester ouieren en esta rasón, pero todavía es mi merced de retener e retengo para mi e para la corona real de mis regnos en la dicha villa e lugares e en cada vno dellos alcaualas e terçias e pedidos e monedas quando los otros de mis regnos me las ouieren a pagar, e la mayoria de la justiçia e mineras de oro e de plata e otros metales e todas las otras cosas e cada vna dellas que pertenesçen al sennorio real soberano e que sen non pueden apartar del. Otrosy es mi merçed quel dicho Johán Pacheco nin sus herederos nin subçesores non puedan enajenar lo susodicho nin cosa alguna nin parte dello en yglesia nin monesterio nin en persona de orden nin de religión nin de fuera de mis regnos syn mi licençia e espeçial mandado. E desto mandé dar esta mi carta firmada de mi nombre e sellada con mi sello. Dada en la noble villa de Valladolid, veynte e seys días de otubre anno del nasçimiento del nuestro sennor Jhesucristo de mill e quatrocientos e quarenta. Yo el rey. Yo el dotor 
Fernando Días de Toledo, oydor e refrendario del rey e su secretario lo fis escreuir por su mandado. E en las espaldas de la dicha carta estaua vna sennal que desía registrada.

E por el vigor de la dicha mi carta de liçençia suso encorporada, el dicho prinçipe, mi muy caro e muy amado fijo, dio vna su carta firmada de su nombre e sellada con su sello a don Juan Pacheco, marqués que ahora es de Villena, mi vasallo e del mi consejo, que a esa sasón era llamado Johán Pacheco, su thenor de la qual es este que se sigue.

Don Enrique por la graçia de Dios, príncipe de Asturias, fijo primogénito heredero del muy alto e muy esclaresçido prínçipe muy poderoso rey e sennor, mi sennor, el rey don Johán de Castilla e de León, e sennor de las cibdades de Segouia e Alcaras e de las villas de Guadalfajara e Carrión e Cáceres e Hutyel e Moya e Biuero e Vetanços, conosçiendo a vos Johán Pacheco, mi criado, fijo de Alfonso Telles Gyrón, vasallo del dicho rey mi sennor, los buenos e leales sennalados seruiçios que vos me auedes fecho e fasedes de cada día quiero vos faser alguna enmienda e remuneraçión e satisfaçión dellos porque sea enxemplo a otros que se esfuerçen a bien seruir al dicho rey, mi sennor, e a mí e por liçençia e consentimiento e otorgamiento que el dicho rey mi sennor me dio e otorgó para lo que adelante se sigue, segund se contiene en vna su carta firmada de su nombre e sellada con su sello su thenor de la qual es este que se sigue.

Don Johán por la graçia de Dios, rey de Castilla, de León, de Toledo, de Gallisia, de Seuilla, de Córdoua, de Murçia, de Jahén, del Algarbe, de Algesira, e sennor de Viscaya e de Molina, acatando los buenos e leales seruiçios que Juan Pacheco, mi donsel e vasallo, fijo de Alfonso Télles Gyrón, mi vasallo, ha fecho e fase de cada día, asy a mi commo al prínçipe don Enrique, mi muy amado muy amado [sic] fijo primogénito heredero, e entendiendo que lo fará e contynuará asy de aquí adelante e en alguna enmienda e remuneraçión de los dichos seruiçios e porque sea enxemplo a otros que siruan bien e lealmente asy a mí commo al dicho prínçipe, mi fijo, por la presente do liçençia e abtoridad e otorgamiento e espreso consentimiento al dicho prínçipe, mi fijo, para que non envargante qualquier proybiçiones, vedamientos e yuybiçiones, condiçiones, modos e cláusulas e defendimientos e otras qualesquier cosas de qualquier manera e efeto, calidad e misterio que en contrario sean o ser puedan, asy las contenidas en las cartas de merçed e graçia e donaçión que yo fyse e dy al dicho prínçipe, mi fijo, de la çibdad de Alcaras e su tierra e término e juredición, commo de la villa de Utyel e su término, e en otra qualquier manera e por qualquier cabsa o rasón que sea o ser pueda, nin otrosy enbargante otro qualquier obstáculo e ynpedimiento de fecho e de derecho que lo enbargar e perjudicar pudiese, el dicho prínçipe, mi fijo, libremente pueda dar e dé al dicho Juan Pacheco por juro de heredad para syenpre jamás para sy e para sus herederos e subçesores e para quien él quesiere e por bien touiere la dicha villa de Utyel con su tierra e término e dystrito, justiçia e jurediçión alta e baxa, çeuil e criminal e mero e misto ynperio, e rentas e pechos e derechos, e penas e calopnias, e con todas las otras cosas pertenesçientes al sennorío de la dicha villa e su tierra de la qual yo ove fecho merçed al dicho prínçipe, mi fijo, en que dis que ay fasta tresientos vasallos, e asy mesmo pueda apartar e aparte de la jurediçión e sennorío e subjeçión e término de la dicha çibdad de Alcaras logares e aldeas de Villanueva de Alcaras e del lugar de Vonillo e del lugar de Lususa e del lugar de Munuera, en los quales dys que ay fasta quinientos vasallos, e los pueda dar e dé por juro de heredad para siempre jamás commo susodicho es al dicho Juan Pacheco, todo esto e cada cosa dello fasta en quantía de ochoçientos vasallos asy en la dicha villa commo en los dichos lugares, e que gelos pueda dar e dé con todos sus términos e dystrito e justiçia e jurediçión ceuil e criminal, e rentas e pechos e derechos 
e penas e calopnias, e con todas las otras cosas e cada vna dellas pertenesçientes al sennorío de los dichos lugares e de cada vno dellos, e le pueda faser e faga merçed e graçia e donaçión e remuneraçión pura, propia, perfeta e non reuocable para syenpre jamás de todo lo suso dicho e de cada cosa e parte dello, e del sennorío e propiedad e tenençia e posesión dello e de cada cosa e parte dello, e gelo dar e enagenar e dar e dé poder e abtoridad e facultad para lo entrar e tomar e tener e poseer e enajenar e faser dello e de cada cosa dello commo de cosa suya propia, libre e quita, e le dar e faser e le dar e faser [sic] e otorgar sobre ello su carta o cartas con qualquier cláusulas e firmesas e juramentos. E yo por la presente fago merçed e graçia e donaçión de todo ello e de cada cosa e parte dello al dicho Johán Pacheco, e que lo do por juro de heredad para siempre jamás segund e por la forma e manera quel dicho prínçipe, mi fijo, gelo diere e otorgare, e ynterpongo mi decreto e avtoridad real a todo ello e a cada cosa e parte dello para que vala e sea firme, estable e valedero para syenpre jamás, non envargantes qualesquier leyes, fueros e derechos, ordenamientos, estylos, costumbres, fasannas e toda otra cosa asy de hecho commo de derecho de qualquier natura, vigor, efeto, calidad e misterio que en contrario sea o ser pueda, avnque fuese tal de lo qual aquí deuiese ser fecha espresa e espeçial mençión, nin otrisy envargantes las leyes que disen que las cartas dadas contra ley o fuero o derecho o ordenamiento deuen ser obedesçidas e non cumplidas avnque contengan qualesquier cláusulas derogatorias e otras firmesas, nin otrosy envargantes las leyes que disen que non pueden ser derogadas salvo por cortes las leyes e fueros e derechos e ordenamientos, cá yo de mi propio motu e çierta çiençia e poderío real absoluto dispongo contra todo ello e contra cada cosa e parte dello, e lo abrogo e derogo, alço e quito e amueuo en todo e por todo en quanto a esto atanne o atanner puede, e indugo contra todo ello e contra cada cosa e parte dello mi plenaria e perfeta dispensaçión, e suplo qualesquier defetos en caso que algunos ouiese o aya o ayan ynteruenido o yntervengan, e asny mismo otras qualesquier cosas asy de sustançia commo de solepnidad o en otra qualquier manera neçesarias e conplidoras e prouechosas de se suplir, e para validaçión e corrovoraçión de todo lo suso dicho e de cada cosa e parte dello, e alço e quito e amuevo e he por non puesta la tal proybiçión e defendimiento, de vadamento e ynibición, allenaçión e condiçión e modo e cláusulas derogatorias, e otras qualesquier cosa o parte dello sean o ser puedan. E do e otorgo e trespaso en el dicho Johán Pacheco e en sus herederos e subçesores la tenençia e posesión e propiedad e sennorío de todo lo susodicho e de cada cosa e parte dello para syenpre jamás, e le do poder e abtoridad e facultad para lo entrar e tomar syn pena e syn calopnia alguna por sy o por otros por él segund e por la forma e manera quel dicho prínçipe, mi fijo, gelo diere e otorgare, e otorgo e prometo por mi fe real de lo asny guardar e conplir e mandar guardar e conplir e de non yr nin venir nin consentyr nin permityr nin dar lugar que persona nin personas algunas de qualquier estado o condiçión, preheminençia o dignidad que sean vayan nin pasen contra ello nin contra cosa alguna nin parte dello agora ni en algund tiempo nin por alguna manera nin cabsa nin rasón que sea o ser pueda. E mando al dicho prínçipe, ni fijo, e a los ynfantes, duques, condes, ricos ommes, maestres de las órdenes, priores, comendadores e subcomendadores, alcaydes de los castillos e casas fuertes e llanas, e a los del mí consejo e oydores de la mi abdiençia, e alcaldes e notarios e alguasiles e otros justiçias e ofiçiales de la mi casa e corte e chançellería, e a los conçejos e vesinos e moradores de la dicha villa e de los dichos lugares e de cada vno dellos, e a todos los conçejos e alcaldes e alguasiles, regidores, caualleros, escuderos e ommes buenos de todas las çibdades e villas e lugares de los mis regnos e sennorios, e otras qualesquier personas mis súbditos e naturales de qualquier estado o condiçión, preheminençia o dignidad que sean, e qualquier o qualesquier dellos que lo guarden e cumplan e fagan guardar e conplir 
bien e conplidamente en todo e por todo segund que se suso se contiene, e que non vayan nin pasen nin consientan yr nin pasar contra ello nin contra cosa alguna nin parte dello agora nin en algund tiempo nin por alguna cabsa nin rasón nin color que sea o ser pueda. E que sobre esto nin sobre cosa alguna nin parte dello non me requieran nin consulten nin atiendan otro mí mandamiento nin segunda jusión, cá mi merçed e voluntad es que esto se faga e cumpla asy. E los vnos nin los otros non fagades ende al por alguna manera sopena de la mi merçed e depuçiçión de los ofiçios e de confyscación de los bienes de los que lo contrario fesieren para la mi cámara. E sobre esto mando al mi chançiller e notarios e a los otros que están a la tabla de los mis sellos que den e libren e pasen e sellen al dicho Johán Pacheco mi carta e preuillejo la más firme e bastante e con las mayores firmesas e cláusulas derogatorias que le conplieren e menester ouiere en esta rasón. Pero todavía es mi merçed de retener e retengo para mí e para la corona real de mis regnos en la dicha villa e lugares e en cada vno dellos alcaualas e terçias e pedidos e monedas quando los otros de mis regnos me las ouieren a pagar, e la mayoría de la justiçia e mineras de oro e plata e otros metales, e todas las otras cosas e cada vna dellas que pertenesçen al sennorío real soberano, e se non pueden apartar dél. E otrosy es mi merçed quel dicho Juan Pacheco nin sus herederos nin subçesores non puedan enajenar lo susodicho nin cosa alguna nin parte dello en yglesia nin monesterio nin persona de orden nin religión nin de fuera de mis regnos syn mi liçençia e espeçial mandado. E desto mandé dar esta mi carta firmada de mi nonbre e sellada con mi sello. Dada en la noble villa de Valladolid, veynte e seys días de otubre, anno del nasçimiento del nuestro sennor Jhesucristo de mill e quatroçientos e quarenta. Yo el rey. Yo el dotor Fernando Días de Toledo, oydor e refrendario del rey e su secretario la fis escreuir por su mandado. Registrada.

Por ende, yo el sobredicho prínçipe don Enrique, de mi libre e agradable voluntad, acatando e consyderando los dichos seruiçios que vos el dicho Juan Pacheco, mi criado, me auedes fecho e fasedes de cada día, e en alguna enmienda e remuneraçión dellos vos fago merçed e graçia e donaçión, pura e propia e non reuocable que es dicha entre biuos por juro de heredad para syenpre jamás para vos e para vuestros herederos e subçesores para quien vos pusiéredes e por bien touiéredes de la dicha mi villa de Vtyel, e asy mesmo de los lugares de Villanueua de Alcaras e del lugar de Bonillo e del lugar de Lesusa e del lugar de Munera, que fueron de la dicha mi çibdad de Alcaras, los quales yo aparté e eximí de la dicha çibdad e de su jurediçión para que fuesen por sy e sobresy, la qual dicha villa e lugares e cada vno dellos vos yo do e fago merçed e graçia e donaçión pura e propia e perfeta para syenpre jamás dellos e de cada vno dellos para que los ayades por juro de heredad para syenpre jamás con todos sus términos e dystritos, justiçia e jurediçión çeuil e criminal, alta e baxa e mero misto ynperio, e vasallos e rentas e pechos e derechos e penas e calonias, e con todas las otras cosas e cada vna dellas pertenesçientes al sennorío de ls dicha villa e lugares e de cada vno dellos, e lo ayades e tengades e poseades vos e vuestros herederos e subçesores después de vos commo cosa vuestra libre e quita, e lo podades vender e enpennar e cambiar e enajenar e faser dello e en ello commo de cosa vuestra propia, tanto que nin podades faser nin fagades lo suso dicho nin cosa alguna nin parte dello con yglesia nin monesterio nin con persona de orden nin de religión ni de fuera de los regnos del dicho rey, mi sennor, syn su liçençia e mandado e mío. E otrosy que queden ende siempre para el dicho rey, mi sennor, e para la corona real de sus regnos, e después de los días del dicho rey, mi sennor, que sean muchos e buenos, para mí commo su fijo primogénito heredero dellos, e para los reyes que después de mí fueren en los dichos regnos, alcaualas e terçias e pedidos e monedas quando las otras çibdades e villas e lugares del dicho rey, 
mi sennor, las auieren a pagar, e la mayoría de la justiçia e mineras de oro e plata e otros metales e todas las otras cosas que pertenesçen al sennorío real e se non pueden apartar dél. E por la presente me desapodero de la tenençia e posesión real, abtual, corporal, cenil e natural e de la detentación e del sennorío e propiedad de las dichas villas e lugares e de cada vno dellos, e lo otorgo e do e trespaso en vos el dicho Juan Pacheco e en vuestros herederos e subçesores después de vos, e vos do abtoridad e poder conplido e facultad para la entrar e tomar e contynuar en caso que falledes ende qualquier resystençia abtual o verbal e avnque todo concurra ayuntada o apartadamente. E por esta mí carta mando a los conçejos, alcaldes, alguasciles, regidores, caualleros, escuderos e ommes buenos de la dicha villa de Utiel e de los sobredichos lugares e de cada vno dellos, e a qualesquier vesinos e moradores dellos e a qualquier o qualesquier dellos, que vos ayan e resçiban por su sennor e vos fagan e exiban toda reuerençia e obediençia e juramento e pleito e omenaje commo a su sennor e cunplan vuestras cartas e mandamientos e vos consyentan vsar de la justiçia e jurediçión alta e baxa, ceuil e criminal e mero e misto ynperio de la dicha villa e lugares e de cada vno dellos a vos e a los que vos posyéredes en vuestro lugar, e vos recudan e fagan recodir con todas las rentas e pechos e derechos e penas e calopnias e con todas las otras cosas pertenesçientes al sennorío de la dicha villa e lugares e de cada vno dellos bien e conplidamente en guisa que vos non mengue ende cosa alguna, e que lo así fagan e cunplan syn me requerir nin consultar sobre ello nin esperar otro mi mandamiento nin segunda iusión. E los vnos nin los otros non fagan ende al por alguna manera sopena de la merçed del rey, mi sennor, e mia, e de priuaçión de los ofiçios e de confiscación de los bienes de los que lo contrario fesieren para la mi cámara. Lo qual todo suso en esta mi carta contenido e cada cosa e parte dello quiero e es mi merçet e voluntad que se faga e cunpla asy, non enbargantes qualesquier leyes, fueros e derechos e ordenamientos, e estilos e costumbres e fasannas e toda otra cosa de fecho e de derecho que en contrario sea o ser pueda de qualquier natura e vigor, calydad e misterio, cá yo de mi propio motu e çierta çiençia lo renunçio e quito e aparto de mi e de mi ayuda e defensión, e asy mesmo todo benefiçio de restytución yn yntegrumd que me conpeta o conpeter pueda contra ello o contra qualquier cosa o parte dello, asy por ser prinçipe commo por rasón de cauallería o por ser menor de hedad de veynte e çinco annos o en otra qualquier manera, e renunçio espresamente las leyes que disen que los derechos proybytivos non pueden ser renunçiados, e que la general renunciaçión non vale sy non proçede la espeçial. E mando e defiendo que ninguna nin algunas personas de qualquier estado o condición, preheminenía o dignidad que sean non sean osados de yr nin pasar nin vayan nin pasen nin consyentan yr nin pasar contra esta dicha donaçión e merced e graçia que yo asy fise e fago a vos el dicho Johan Pacheco de las dicha villa e lugares e de todo lo suso dicho e de cada cosa e parte dello, nin contra lo en esta mi carta contenido nin contra cosa alguna dello por cabsa nin rasón nin color que sea o ser pueda, más que vos anparen e defiendan con esta merçed e graçia e donaçión que vos yo asy físe e fago por tal manera que la ayades para siempre jamás, firme e estable. E los vnos nin los otros non fagan ende al por alguna manera so la dichas penas, sobre lo qual mando al mi chanciller e a los otros que están a la tabla del mi sello que vos den e libren e pasen e sellen mi carta de preuillejo la más firme e vastante que vos cunpliere e menester ouiéredes en esta rasón. E juro e prometo en mi buena fe commo prínçipe fijo de rey, primogénito heredero, e así mismo juro al nonbre de Dios e a esta sennal de crus e a las palabras de los santos euangelios corporalmente con mi mano tannidos do quier que están de guardar e conplir e mandar guardar e conplir realmente e con efeto para syenpre jamás esta dicha merçed e graçia e donación que vos yo asy fise e fago commo dicho es todas las cosas e cada vna dellas en esta mi carta contenidas, e de non 
yr nin pasar nin consentyr yr nin pasar contra ello nin contra cosa alguna nin parte dello agora nin en algund tiempo nin por alguna manera nin cabsa nin rasón nin color que sea o ser pueda yo nin otro por mi en juysio nin fuera de juysio nin reuocar nin limitar nin condiçionar nin alterar esta dicha merçed e graçia e donaçión que vos yo asy fyse e fago en todo nin en parte nin en cosa alguna en tiempo alguno nin por cabsa alguna, más de vos anparar e defender con ella e de vos la faser sana e paçifyca por tal manera que la ayades libremente para syenpre jamás, e de non pedyr nin demandar venefiçio de restytuçión yn yntegrumd contra ella nin contra cosa alguna nin parte della por las cabsas suso dichas nin por alguna dellas nin por otra alguna nin pedir nin demandar asolución nin dispensaçión nin relaxaçión contra este dicho juramento nin vsar dello en caso que propio motu o a mi postulaçión o de otro me fuese otorgada por el papa o por otro alguno que poder aya de la dar e otorgar, más que syenpre guardaré e conpliré e mandaré guardar e conplir todo lo suso dicho e cada cosa e parte dello realmente e con efeto commo suso dicho es. De lo qual todo mandé dar esta mi carta firmada de mi nonbre e sellada con mi sello. Dada en la noble villa de Valladolid veynte e ocho días de otubre, anno del nasçimiento del nuestro sennor Jhesucristo de mill e quatroçientos e quarenta. Yo el prínçipe. Yo el dotor Fernando Días de Toledo, oydor e refrendario del rey e del su consejo e su secretario, la fis escreuir por mandado de nuestro sennor el prínçipe. Registrada.

E el dicho don Johan Pacheco, marqués de Villena, pedióme por merçed que aprouase e confirmase las dichas cartas e todo lo en ellas e en cada vna dellas contenido, e que le mandase dar mis cartas e preuillejos sobre la dicha rasón. E yo tóuelo por bien, e por esta mi carta de mi çierta çiençia confirmo e aprueuo la dicha mi carta e asy mismo la sobre dicha carta del dicho prínçipe, mi fijo, suso encorporadas e todo lo en ellas e en cada vna dellas contenido, e vos mando que veades las dichas cartas e dedes e libredes sobre ello e pasedes a los mis sellos al dicho marqués don Johán Pacheco mis cartas e preuillejos de las cosas sobre dichas e de cada vna dellas las más firmes e vastantes que menester ouiere en la dicha rasón. E non fagades ende al por alguna manera sopena de la mi merçed. Dada en la muy noble çibdad de Toledo dies días del mes de desienbre, anno del nasçimiento del nuestro sennor Jhesucristo de mill e quatroçientos e quarenta e cinco annos. Yo el rey. Yo el dotor Fernando Días de Toledo, oydor e refrendario del rey e su secretario, la fis escreuir por su mandado. Registrada.

E agora por quanto vos el dicho Johán Pacheco, marqués de Villena, mi vasallo e del mi consejo, e mayordomo mayor del dicho prínçipe don Enrique, mi muy caro e muy amado fijo, me pedistes por merçed que por que mejor e más conplidamente vos valiesen e fuesen guardadas las dichas mis cartas e otrosy la dicha carta del dicho prínçipe, mi fijo, en la sobredicha mi carta ynclusas e cada vna dellas, e asy mesmo vos o aquél o aquellos que de vos o dellos ouiesen cabsa e dependençia podiésedes e pueda vsar e gosar para syenpre jamás de las dichas merçedes por el dicho prínçipe, mi fijo, a vos fechas por la sobredicha su carta por juro de heredad para siempre jamás de la dicha villa de Vtyel e de los dichos lugares de Villanueua de Alcaras e del Bonillo e de Lesusa e de Munuera con sus tierras e términos e distrito e justiçia e jurediçión alta e baxa, ceuil e criminal e mero e misto ynperio e pechos e derechos e penas e calopnias, e de todas las otras cosas pertenesçientes al sennorío de la dicha villa e lugares e su tierra e de lo en esta dicha carta del dicho prínçipe, mi fijo, e en las dichas mis cartas contenido, e otrosy de la dicha lyçençia e abtoridad que yo por ellas dy al dicho prínçipe, mi fijo, e asy mesmo a vos fyse, e de todas las otras merçedes e graçias e cosas en las dichas mis cartas e en la dicha carta del dicho prínçipe, mi fijo, e en cada vna dellas yncluso e contenido e de cada cosa dello, e vos fuese guardado e mantenido en todo tiempo que vos confirmase e aprouase las 
sobredichas mis cartas, e otrosy la dicha carta del dicho príncipe, mi muy caro e muy amado fijo, en la sobredicha mi carta ynclusas, e vos mandase dar sobre ello mi carta de preuillejo rodado e escripto en pargamino de cuero e sellado con el mi sello de plomo pendiente en fylos de seda.

E yo el sobredicho rey don Johán, acatando los buenos e leales seruiçios que vos el dicho marqués don Johán Pacheco auedes fecho asy a mi commo al dicho prínçipe, mi fijo, e entyendo que de aquí adelante a mi e a él faredes, e por vos faser bien e merçed tóuelo por bien, e por este mi preuillejo de mi çierta çiençia vos confirmo e aprueuo la dicha carta del dicho prínçipe, mi fijo, en la sobredicha mi carta ynclusa e las dichas merçedes e graçias e cosas por el dicho prínçipe, mi fijo, por ella a vos el dicho don Johán Pacheco, marqués de Villena, fechas de la dicha villa de Vtyel e de los dichos lugares de Villanueva de Alcaras e del Bonillo e de Lesusa e Munuera, e de lo otro en la sobredicha carta del prínçipe, mi fijo, contenido e cada cosa e parte dello. E otrosy vos confirmo e aprueuo las dichas mis cartas e la dicha liçençia e abtoridad por ellas dada al dicho prínçipe, mi fijo, para lo que de suso dicho es e en ellas e en cada vna dellas se contiene. E otrosy vos confirmo e aprueuo la dicha confirmaçión e aprouaçión por mi fecha por las dichas mis cartas e por cada vna e qualquier dellas de las sobredichas merçedes a vos fechas por el dicho prínçipe, mi fijo, de la dicha villa e de los dichos lugares e de lo otro en ellas e en cada vna dellas contenido, e mando que vala e sea todo guardado a vos el dicho don Johán Pacheco, marqués, e a los dichos vuestros herederos e subçesores e aquél o aquellos que de vos o dellos ouieren cabsa e dependençia para siempre jamás, e quiero e es mi merçed que ayades la dicha villa de Vtyel e los dichos lugares de Villanueva de Alcaras e del Vonillo e de Lesusa e de Munuera e vasallos de la dicha villa e lugares e todo lo otro susodicho por juro de heredad segund e conmo e en la manera e forma que en las mis cartas e en la dicha carta del dicho prínçipe, mi fijo, se contiene, tanto que vos nin los dichos herederos e subçesores nin aquel o aquellos que de vos o dellos ouieren cabsa e dependençia que non lo podades nin puedan vender nin enpennar nin cambiar nin enajenar nin faser de la dicha villa e lugares nin de alguno dellos nin de lo otro que dicho es a yglesia nin con yglesia nin monasterio nin con persona de orden nin de relygión nin de fuera de mis regnos syn mi liçençia e mandado. Otrosy es mi merçed que syenpre quede en la dicha villa e en los dichos lugares e sus tierras e términos para my e para los reyes que después de my fueren e para la corona real de mis regnos alcaualas e terçias e pedidos e monedas quando los otros de mis regnos me las ouieren a dar e pagar, e la mayoría de la justiçia e mineras de oro e de plata e de otros metales, e todas las otras cosas e cada vna dellas que pertenesçen al sennorío real soberano e se non pueden apartar dél.

E por este mi preuillejo o por su traslado abtorisado en manera que faga fe mando e defiendo firmemente que alguno nin algunos non sean osados de yr nin pasar nin contradesir a vos nin a los dichos vuestros herederos e subçesores nin aquél o aquellos que de vos o dellos ouieren cabsa dependençia nin a alguno dellos contra la dicha carta del dicho prínçipe, mi fijo, nin contra la merçed e cosas en ella contenidas nin contra las dichas mis cartas e liçençia e abtoridad e confirmaçión e merçed e aprouaçión por mí por ellas fechas nin contra lo otro que dicho es en ellas contenido nin contra este mí preuillejo nin contra cosa alguna nin parte dello por la quebrantar o menguar en algund tiempo nin por alguna manera nin rasón nin color que sea o ser pueda, cá qualquier o qualesquier que los fesieren non los valdría e yo desde agora mando que les non vala e avría la mí yra e a sus cuerpos e a lo que ouiesen me tornaría e pecharme ya, e yo desde agora mando que me pechen la pena en las sobredichas mis cartas contenidas e más dos mill doblas de oro castellanas e a vos el dicho Johán Pacheco, marqués de Villena, mi vasallo e del mi consejo, e a vuestros 
herederos e subçesores o a quien vuestra ves o suya touiere todas las costas e dannos e menoscabos que por ende resçibiéredes o fesiueren doblados.

Sobre lo qual todo que de suso dicho es e sobre cada cosa e parte dello por este mí preuillejo o por su traslado synado commo dicho es mando al dicho prínçipe, mi muy caro e muy amado fijo, e a los duques, marqueses, condes, maestres de las órdenes, prelados, priores, ricos ommes e a los del mi consejo e al mi justiçia mayor e oydores de la mi abdiençia, e alcaldes e notarios e jueses e alguasiles e notarios e justiçias e ofiçiales qualesquier de la mi casa e corte e chançellería, e a los mis adelantados e merinos, e a los comendadores e subcomendadores, alcaydes de los castillos e casas fuertes e llanas e otros aportellados qualesquier, e a todos e qualesquier mis vasallos e otras qualesquier personas mis súbditos e naturales de qualquier estado o condición, preheminençia o dignidad que sean, que guarden e cunplan e fagan e manden guardar e conplir todo lo en la sobredicha carta de la dicha merçed del dicho prínçipe, mi fijo, e en las sobredichas mis cartas e en cada vna dellas contenido e otrosí lo contenido en este dicho mi preuillejo e cada cosa e parte dello, e que non vayan nin pasen nin consyentan yr nin pasar contra ello nin contra parte dello en algund tiempo nin por alguna manera rasón nin color que sea so las dichas penas, e sy alguno o algunos contra ello o contra alguna cosa o parte dello fueren o pasaren o quesieren yr o pasar que gelo non consientan, más que anparen e defiendan en todo ello con las dichas mis cartas e otrosy con la dicha carta del dicho prínçipe, mi fijo, suso encorporadas, e con este dicho mi preuillejo a vos e a vuestros herederos e subçesores e aquél o aquellos que de vos o dellos ouieren causa e dependençia e a cada vno dellos en la dicha merçed e en todo lo otro que dicho es e sobre ello e sobre cada cosa dello, e que prendan en vienes de aquél o aquellos que contra ello o contra parte dello fueren o pasaren por las dichas penas e las guarden para faser dellas lo que la mi merçed fuere, e que emienden e fagan emendar a vos el dicho don Johán Pacheco, marqués de Villena, e a los otros que dichos son e a cada vno de vos e dellos o a quien vuestra bos o suya touiere de todas las costas e dannos e menoscabos que por ende se vos o les recreçieren doblados bién e conplidamente en guisa que a vos nin a ellos non mengue ende cosa alguna. E demás por qualquier o qualesquier por quien fyncare de lo asy faser e conplir mando al omme que les este mi preuillejo mostrare o el dicho su treslado signado commo dicho es que los enplase que parescan ante mí en la mi corte del día que los enplasare fasta quinse días primeros seguientes so las dichas penas a cada vno, so las quales mando a qualquier escriuano público que para esto fuere llamado que dé dello testymonio signado con su signo porque yo sepa en commo se cumple mi mandado.

E desto vos mandé dar este mi preuillejo escripto en pargamino de cuero rodado e sellado con mi sello de plomo pendiente en fylos de seda a colores. Dado en la çibdad de Toro dies e siete días del mes de mayo, anno del nasçimiento del nuestro saluador Jhesucristo de mill e auqtroíentos e quarenta e seys annos. Va escripto en renglones o dis e de e o dis nin e o dis vayan e o dis me las e o dis dicho e o dis don Enrique e o dis onde e o dis lo e o dis la e o dis de e o dis vos do e o dis que e o dis de mi e o dis de e o dis de cada vna dellas bien e conplidamente en guisa que le non mengue ende e o dis e sellen e o dis e vos do e o dis más e dis por e o dis que e sobre raydo o dis cunpla e o dis mineras e o dis algunos en dos lugares raydo e puesta en la raedura dos rayas de tinta.

E yo el sobredicho rey don Johán, reynante en vno con el prínçipe don Enrique, mi fijo, en Castilla, en León, en Toledo, en Gallisia, en Seuilla, en Córdoua, en Murçia, en Jahén, en el Algarbe, en Algesira, en Baeça, en Vadajos, en Viscaya, en Molina, otorgo este preuillejo e confírmolo e confirma, don Aluaro de Luna, maestre de la orden de la cauallería de Santiago, e condestable de Castilla e conde de 
Alburquerque, confirma; don Fadrique, primo del rey, almirante mayor de la mar, confirma; don Johán de Gusmán, primo del rey, duque de Medina Sydonia e conde de Niebla, vasallo del rey, confirma; don Ynnygo Lópes de Mendoça, marqués de Santillana, conde del Real de Mançanares e sennor de las Casas de Mendoça e de la Vega, vasallo del rey, confirma; don frey Pedro Girón, maestre de la orden de cauallería de Calatraua, confirma; don frey Gutierre de Sotomayor, maestre de Alcántara, confirma; don frey Gonçalo de Quiroga, prior de Sant Juan, confirma; don Alfonso Pimentel, conde de Benauente, vasallo del rey, confirma; don Loys de la Çerda, conde de Medina Cely, vasallo del rey, confirma; don Pedro, sennor de Monte Alegre, vasallo del rey, confirma; don Alvaro de Ysorna, arçobispo de Santiago, capellán mayor del rey, confirma; don Juan de Ceruantes, cardenal de Sant Pedro, administrador perpetuo de la yglesia de Segouia, confirma; don Alfonso de Santa María, obispo de Burgos, confirma; don Pedro, obispo de Palençia, confirma; don Lope de Barrientos, obispo de Cuenca, confirma; don Alfonso de Fuent seca, obispo de Auila, confirma; don Alfonso Carrillo, obispo de Çiguença, confirma; don Sancho, obispo de Cordoua, confirma; don frey Juan, cardenal de Sant Systo, administrador perpetuo de la yglesia de Orense, confirma; don Gonçalo, obispo de Jahén, confirma; don Pedro, obispo de Calahorra, confirma; don Gonçalo, obispo de Plasençia, confirma; don [en blanco], obispo de Cádys, confirma; Diego Manrique, adelantado mayor del reuno de León, confirma; don Diego Sarmiento, conde de Santa Marta, adelantado mayor de Gallisia, vasallo del rey, confirma; Per Afán de Ribera, adelantado e notario mayor del Andalusía, confirma; Pedro Fajardo, adelantado mayor del reyno de Murçia, confirma; Juan de Sylua, alferese mayor del rey e notario mayor de Toledo, confirma; Pero Sarmiento, repostero mayor del rey, confirma; Johán Ramires de Arellano, sennor de los Cameros, vasallo del rey, confirma; don Pedro de Guevara, sennor de Onante, vasallo del rey, confirma; don Pedro de Ayala, merino mayor de Guipúscoa, confirma; Pero Lopes de Ayala, aposentador mayor del rey e su alcalde mayor de Toledo, confirma; la yglesia de Toledo, vaca, confirma; don Pedro de Astunniga, conde de Plasençia, justiçia mayor de la corte del rey, confirma; don Pero Ferrándes de Velasco, conde de Haro, sennor de la casa de Salas, camarero mayor del rey, confirma; don Garçía Enriques, arçobispo de Seuilla, confirma; don [en blanco], obispo de Ouiedo, confirma; don Pero Vaca, obispo de León, confirma; don Ruberto de Moya, obispo de Osma, confirma; don Johán de Mella, obispo de Zamora, confirma; la yglesia de Salamanca, confirma; don [en blanco], obispo de Coria, confirma; don [en blanco] obispo de Badajos, confirma; don Aluar Peres, obispo de Astorga, confirma; don Alfonso, obispo de Çibdad Rodrigo, confirma; don Garçía, obispo de Lugo, confirma; don [en blanco], obispo de Mondonnedo, confirma; don Loys Pementel, obispo de Tuy, confirma; don Johán, conde de Armenaque e de Cangas e Tyneo, vasallo del rey, confirma; don Johán Manrique, conde de Castanneda, chanciller mayor del rey, confirma; don Pero Ponce de León, conde de Arcos, vasallo del rey, confirma; don Fernand Alvares de Toledo, conde de Alua, vasallo del rey, confirma; don Pero Aluares Osorio, conde de Trastámara, sennor de Villalobos, vasallo del rey, confirma; don Pero Ninno, conde de Guelma, sennor de Çigales, confirma; don Rodrigo de Villandrano, conde de Ribadeo, vasallo del rey, confirma; don Pedro de Acunna, conde de Valençia, confirma; don Gonçalo de Gusmán, conde de Gelues, vasallo del rey, confirma; don Alfonso de Gusmán, sennor de Orgas, alguasil mayor de Seuilla, confirma; don Pedro, sennor de Aguilar, vasallo del rey, confirma; Diego Ferrándes, sennor de Vaena, mariscal de Castilla, confirma; Pero Garçía de Herrera, maryscal de Castilla, confirma; Pedro de Mendoça, sennor de Almaçán, vasallo del rey, confirma. El dotor Fernando Días de Toledo, relator del rey e su refrendario e notario mayor de los preuillejos rodados, 
confirma. Yo Johán Sánches de Valladolid, escriuano del dicho sennor rey lo fise escreuir por su mandado.

E leyda la dicha carta de preuillejo, el dicho sennor don Johán Pacheco, marqués, dixo que por quanto él se entendía aprouechar de la dicha carta de preuillejo origynal del dicho sennor rey para lo leuar o enviar a algunas personas donde le conplía, e se reçelaua que se podría perder por agua o por fuego o por furto o por robo o por otra ocasyón que en él podría acaesçer, por ende pedió al dicho alcalde que diese liçençia a mi el dicho escriuano para que sacase o fesiese sacar la dicha carta de preuillejo origynal del dicho sennor rey vn traslado o dos o más quantos él quisiese e menester ouiese, e los signase de mi signo e ynterposiese a ellos e a cada vno dellos su abtoridad e decreto para que valiesen e fesiesen fe en juisio e fuera dél doquier que paresçiese bien asy e a tan conplidamente commo la dicha carta de preuillejo origynal del dicho sennor rey valería e faría paresçiendo. E luego el dicho alcalde tomó la dicha carta de preuillejo del dicho sennor rey en las manos e católa e esaminóla, e dixo que por quanto lo veya sano e non roto nin chançellado nin en alguna parte dél sospechoso, por ende dixo que daua e dio liçençia a mi el dicho escriuano para que sacase o fesiese sacar de la dicha carta de preuillejo oryginal del dicho sennor rey vn traslado o dos o más quantos el dicho sennor marqués quesiese e menester ouiese, e los signase de mi signo, e que al traslado o traslados que yo asy sacase e fesiese sacar de la dicha carta de preuillejo oryginal del dicho sennor rey e fuesen signados de mi signo que él ynterponía e ynterpuso a ellos e a cada vno dellos su abtoridad e decreto en quanto podía e deuía de derecho porque vala e tenga fe en juisio e fuera dél en qualquier lugar do paresçiere, bien asy e a tan conplidamente commo la dicha carta de preuillejo orygynal del dicho sennor rey valería e faría paresçiendo.

E desto en commo pasó el dicho sennor don Johán Pacheco, marqués, pedió a mí el dicho escriuano que gelo diese signado de mi signo para guarda de su derecho. Testigos que fueron presentes a esto Juan de Haro e Fernando del Castillo, camarero del dicho sennor marqués, e Juan del Real, escudero del dicho Fernando del Castillo.

E yo Diego Rodrigues, escriuano público sobredicho fuy presente a esto que dicho es con los dichos testigos, e vy e ley la dicha carta de preuillejo origynal del dicho sennor rey, e por la liçencçia quel dicho alcalde me dio a pedimiento del dicho sennor marqués fis sacar della este traslado e lo concerté con ella ante los dichos testigos, e va çierto e escripto en siete foias de papel de pliego entero escriptas de amas partes con esta foia en que va mi signo e de yuso de cada plana va puesta vna robrica de mi nonbre. E por ende fis aquí este mío signo en testimonio.

Diego Rodrigues.

Fecha de recepción del artículo: enero 2009.

Fecha de aceptación y versión final: junio 2009. 